INTER NATIONAL MONETARY FUND
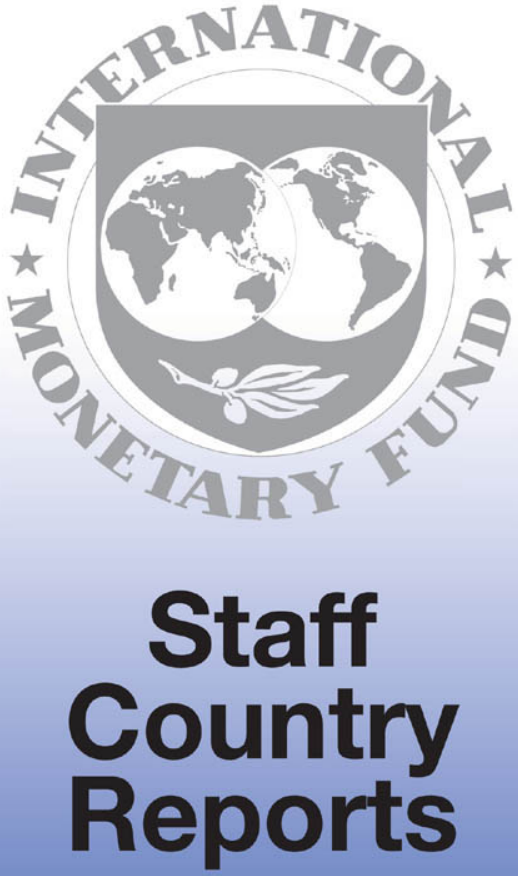


\section{Spain: Selected Issues}

This Selected Issues report on Spain was prepared by a staff team of the International Monetary Fund as background documentation for the periodic consultation with this member country. As such, the views expressed in this document are those of the staff team and do not necessarily reflect the views of the government of Spain or the Executive Board of the IMF.

Copies of this report are available to the public from

International Monetary Fund - Publication Services

70019 th Street, N.W. - Washington, D.C. 20431

Telephone: (202) 623-7430 - Telefax: (202) 623-7201

Telex (RCA): 248331 IMF UR

E-mail: publications@imf.org

Internet: http://www.imf.org

Price: $\$ 15.00$ a copy

\section{International Monetary Fund Washington, D.C.}


This page intentionally left blank 
INTERNATIONAL MONETARY FUND

SPAIN

\section{Selected Issues}

Prepared by C. M. Watson, Philip Gerson, Mario Mesquita (all EU1), Antonio Spilimbergo, Paolo Mauro (both RES) and Elisa Muzzini (Intern, EU1)

Approved by European I Department

October 6,2000

Content

Structural Change in the Public Finances.............................................................. 3

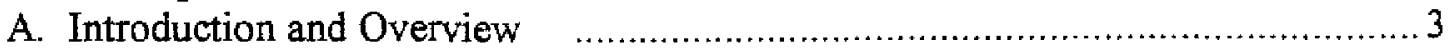

B. Background: the Present Structure ............................................................ 4

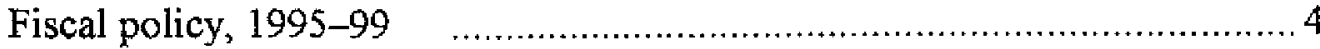

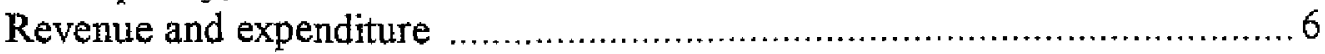

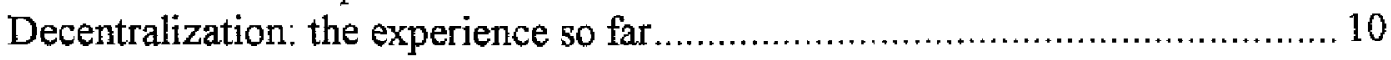

C. Challenges for the Medium and Long Term .............................................13

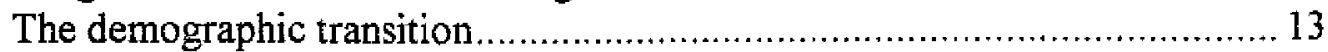

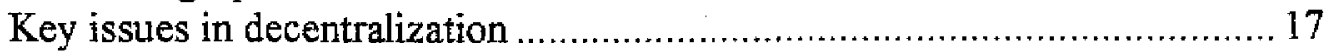

Supporting growth and employment in the coming decade ........................ 19

D. Concluding Remarks

.24

Tables

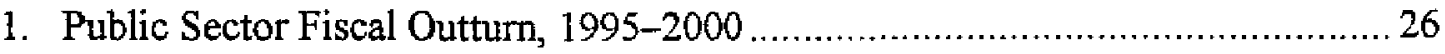

2. Public Finances, Baseline Scenario, 1998-2050 .......................................27

2a. Public Finances, Alternative Scenario with Reduction in Early

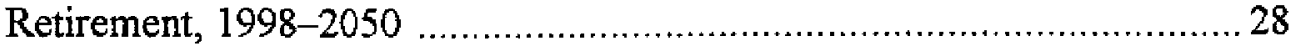

2b. Public Finances, Alternative Scenario with Reduction and Labor

Market Reforms, 1998-2050 ........................................................29

3. Volatility of Tax Bases and Revenues by Region ........................................30

4. Per Capita Value Added by Region, 1985-98 ........................................... 31

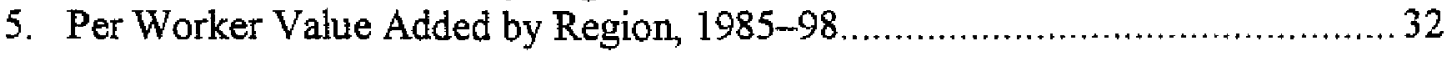

Figures

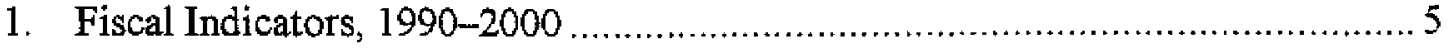

2a. Composition of Fiscal Adjustment, 1995-99 …….....................................

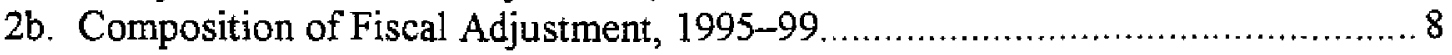

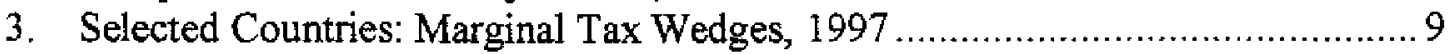

4. Selected Countries: Public Expenditure, 1999 …....................................... 11 
Appendices

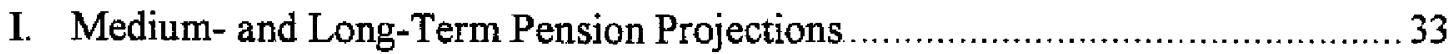

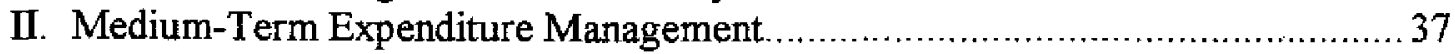

III. Physical Capital Adjustment Within Spain: Long- and

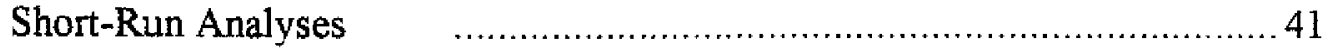

IV. An Analysis of the Role of Public Capital in Regional Growth in Spain ............ 58 


\section{Structural, Change in the Public Finances ${ }^{1}$}

\section{A. Introduction and Overview}

1. In recent years, the overall health of the Spanish public finances has improved dramatically. Fiscal deficits that less than a decade ago stood in excess of 7 percent of GDP have been brought nearly to zero, primarily through expenditure restraint. The regional and local governments have, in aggregate, reduced deficits that stood at over 7 percent of GDP in the early 1990 s to near balance today; and a series of structural reforms has enabled the pension system to move from deficits of $3 / 4$ percent of GDP in the early and mid-1990s to a small cashflow surplus. Public debt levels (about 63 percent of GDP in 1999) are on a declining trend. Fiscal retrenchment-and the resulting expectation that Spain would qualify for Stage 3 of monetary union-generated positive confidence effects that resulted in faster output growth and lower interest rates, creating a virtuous cycle that further strengthened the fiscal outlook.

2. With fiscal balance being targeted in 2001 , it would be easy to conclude that the process of fiscal reform is now largely complete. Nevertheless, despite the very healthy short-term outlook for the public finances, issues remain that-unresolved-have the potential to erode the strength of the public sector accounts in the medium or longer term. As in most industrial countries, the coming demographic transition will put considerable pressure on health and pension expenditure over the long term. Meeting this challenge will require spending reforms to reduce future costs, the accumulation of surpluses over the medium term to pre-fund spending, or-if the system is to continue operating on a pay-asyou-go basis - very large increases in tax rates in the future. In addition, the current mechanism for financing the expenditures of regional and municipal governments is due to expire at the end of next year. Negotiating a successor arrangement that successfully balances solidarity concerns with the need to give regions greater control over their own revenues, and that does not weaken overall expenditure control, will be a complicated matter. Finally, there is a need to respond to these challenges while maintaining a fiscal environment that is supportive of employment and output growth in the medium term, and that helps foster over time a decline in the significant variations in per capita income across regions.

3. This paper examines these challenges and explores possible policy responses to meet them. Section B provides background on the present structure of the fiscal accounts. Section $\mathrm{C}$ reviews the challenges confronting fiscal policy makers in more detail and indicates possible roads for reform. Section $\mathrm{D}$ concludes. In responding to many of these challenges, the authorities envisage extending the consensus-based approach to reform that has served them well in recent years. In this spirit, the goal of this paper is not to detail a prespecified set of policy reforms, but rather to highlight the importance of the coming

\footnotetext{
${ }^{1}$ Prepared by Philip Gerson (EU1) with contributions from Messrs. Watson, Mesquita (both EU1), Mauro, Spilimbergo (both RES), and Ms. Muzzini (intern, EU1).
} 
challenges and to illustrate some of the tradeoffs and connections among measures that could be introduced to address them. In some cases - particularly with respect to the impact of population aging on the public finances - the full impact of the pending challenges is expected to arrive later than in most EU members. This affords the authorities and the social partners the scope to consider carefully the various options available to them; but the fact that the impact will only manifest itself over the longer term is not an argument to delay action in the near future if the problem is to be addressed by approaches that are supportive of growth and employment.

\section{B. Background: The Present Structure}

\section{Fiscal policy, 1995-99}

4. The general government in Spain is composed of the State (central) government, the social security system, 17 regional governments and a very large number of municipalities. Over the last several years, motivated in part by a desire to qualify for participation in Stage 3 of monetary union, the Spanish authorities have achieved impressive fiscal consolidation. Between 1995 and 1999, for example, the deficit of the general government has fallen by $51 / 2$ percentage points of GDP, from about $6 \frac{1}{2}$ percent to around 1 percent (Table 1 and Figure 1), and the authorities aim at achieving overall fiscal balance next year. All clements of the general government have contributed to this improvement: over the period in question, the deficit of the State government fell by $4 \frac{1}{2}$ percentage points of GDP and that of the regional and municipal governments by $1 / 2$ percentage point of GDP, while the social security system moved from a deficit of about $1 / 4$ percentage point of GDP to a surplus of the same magnitude.

5. To be sure, some of the improvement in Spain's public finances reflects cyclical factors such as the strong growth of real output in recent years, which averaged more than $31 / 2$ percent in the period 1996-99. Nevertheless, the structural balance, which abstracts from the impact of economic cycles, showed an improvement of four percent of GDP. The public finances also benefited from the decline in interest rates that accompanied Spain's successful drive to euro membership: interest spending fell by $1 \frac{1 / 2}{2}$ percent of GDP over the period. Thus, the structural primary balance improved by $2 \frac{1}{2}$ percent of GDP between 1995 and 1999.

6. Spain's success in reducing the fiscal deficit in recent years compares favorably with the experience of the last cyclical upswing, during the period 1987-91. Substantial progress in deficit reduction that had occurred during the second half of the 1980 s unraveled in the early 1990 s, with the public sector deficit-which had fallen by some 4 percent of GDP between 1985 and 1989 -widening by $11 \frac{1}{2}$ percent of GDP in the subsequent two years. Fiscal consolidation had in fact largely run out of steam by the time the upswing began, as the primary structural deficit widened by about 2 percent of GDP between 1987 and 1991, due-among other factors-to increases in capital expenditure and public sector employment by regional governments. The current upswing dating from 1994 has therefore been marked not only by significant fiscal consolidation that has moved the overall public sector to the 
Figure 1. Spain: Fiscal Indicators, 1990-2000

GENERAL GOVERNMENT BALANCE

(In percent of GDP)

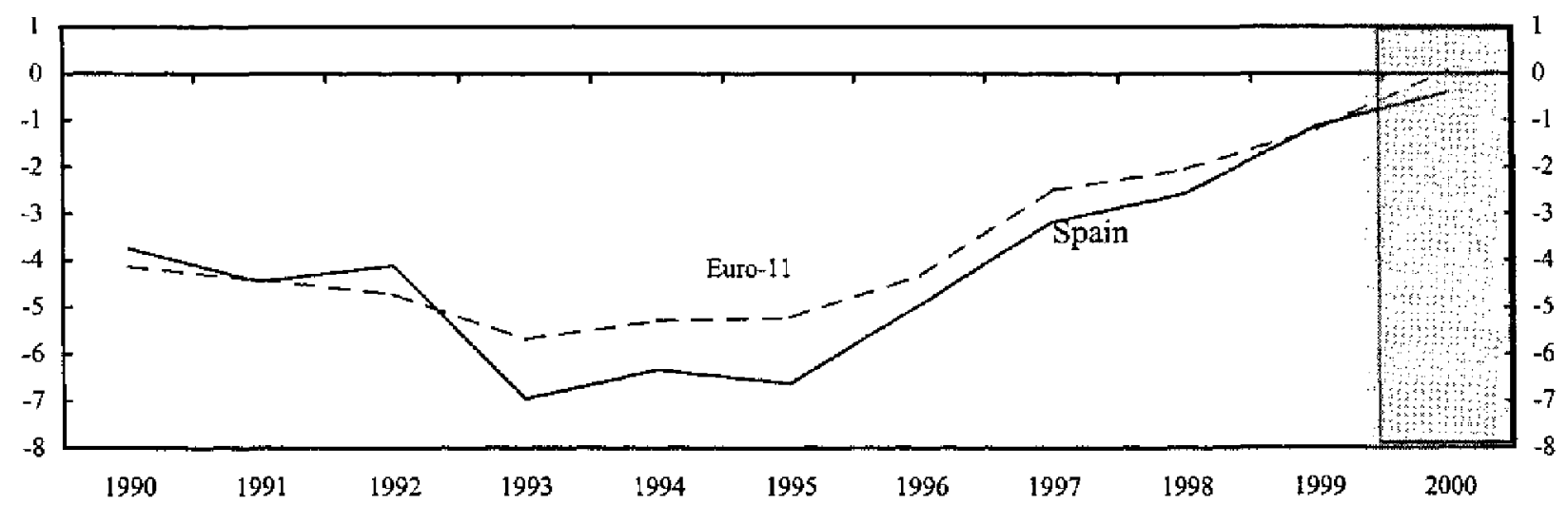

GENERAL GOVERNMENT STRUCTURAL BALANCE

(In percent of potential output)

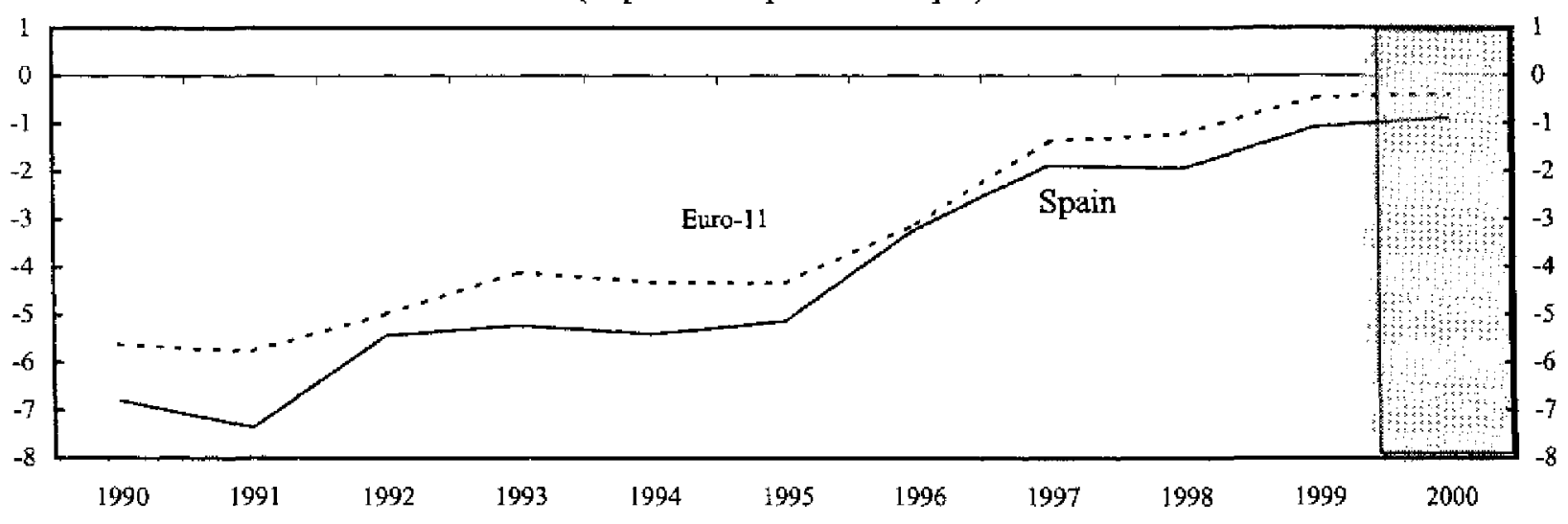

GENERAL GOVERNMENT PRIMARY STRUCTURAL BALANCE

(In percent of potential output)

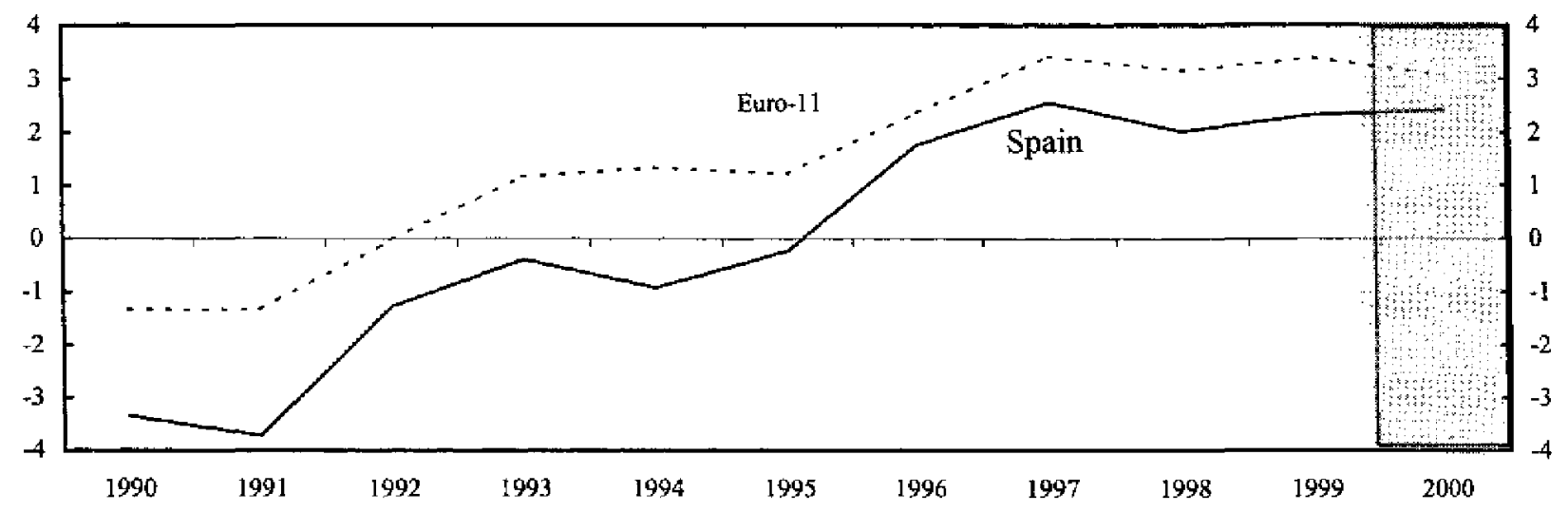

Sources: World Economic Outlook; and Fund staff projections. 
threshold of budgetary balance but also by a shift away from the procyclical fiscal stance that accompanied the last economic expansion.

7. Spain's deficit reduction effort over the last five years is also noteworthy becausemore so than in the larger euro-area economies-it relied for the most part on primary expenditure reduction rather than on revenue increases. While the revenue ratio did increase by 1 percent of GDP between 1995 and 1999, primary expenditure fell by nearly 3 percent of GDP over the same period. Thus, of the 4 percent of GDP improvement in the primary balance between 1995 and 1999, only about 25 percent came from the revenue side. Among euro area countries, only Austria, Finland and Ireland (all of whom actually reduced revenues over the period) and the Netherlands achieved a smaller percentage of primary fiscal adjustment via revenues than did Spain (Figures $2 \mathrm{a}$ and $2 \mathrm{~b}$ ).

\section{Revenue and expenditure}

8. In part as a result of the success in reducing expenditure, the revenue ratio in Spain is significantly lower than the euro-area average: in 1999, total revenues in Spain stood at just under 40 percent of GDP, the second lowest such ratio in the area (after Ireland), compared to an average of more than 47 percent for the euro-area as a whole. Moreover, the tax wedge on labor in Spain is notably lower than in the larger euro-area countries. In 1997, the marginal tax wedge on an unmarried individual earning a wage equal to that of the average production worker was 44 percent in Spain, compared to 63 percent in Germany, 60 percent in Italy and 54 percent in France (Figure 3). ${ }^{2}$ The average income tax rate in Spain (13.8 percent for unmarried individual earning 100 percent of the average production worker's wage) is lower than in Germany (21.2 percent) and Italy (18.8 percent), but slightly higher than in France (10.5 percent). Other elements of the wedge-including social security contributions (employer plus employee) - are lower in Spain than in all three of the largest euro area countries (averaging 25.2 percent in Spain, 38.2 percent in France, 32.7 percent in Italy, and 31.1 percent in Germany for the typical unmarried worker).

9. Tax revenues in Spain, which account for some 90 percent of total revenues, are divided roughly equally among direct, indirect and social security taxes as a share of GDP. The overall tax ratio has risen steadily from 33.3 percent of GDP in 1995 to 35.0 percent in 1999, primarily due to an increase in revenues from indirect taxes, especially the VAT.

About three-fourths of direct tax revenue comes from the personal income tax. A little more

${ }^{2}$ Data are from OECD (1998) The Tax/Benefit Position of Employees. Of course, the size of the maginal tax wedge will vary depending on the income and family status of the worker, as well as on other factors. For an unmarried individual earning 67 percent of the wage of an average production worker, the marginal tax wedge was 47 percent in Spain, 74 percent in France, 60 percent in Germany and 55 percent in Italy. Figures for Spain do not include the impact of the reform to the personal income tax implemented last year, which reduced marginal tax rates. 
Figure 2a. Selected Countries: Composition of Fiscal Adjustment, 1995-99 1/ (Cumulative change, in percent of GDP)


Sources: IMF, World Economic Outlook; and Fund staff estimates.

1/ Euro area figures are unweighted averages.

2/ Excludes capital transfers. 
Figure 2b. Selected Countries: Composition of Fiscal Adjustment, 1995-99 1/ (Cumulative change, in percent of GDP)
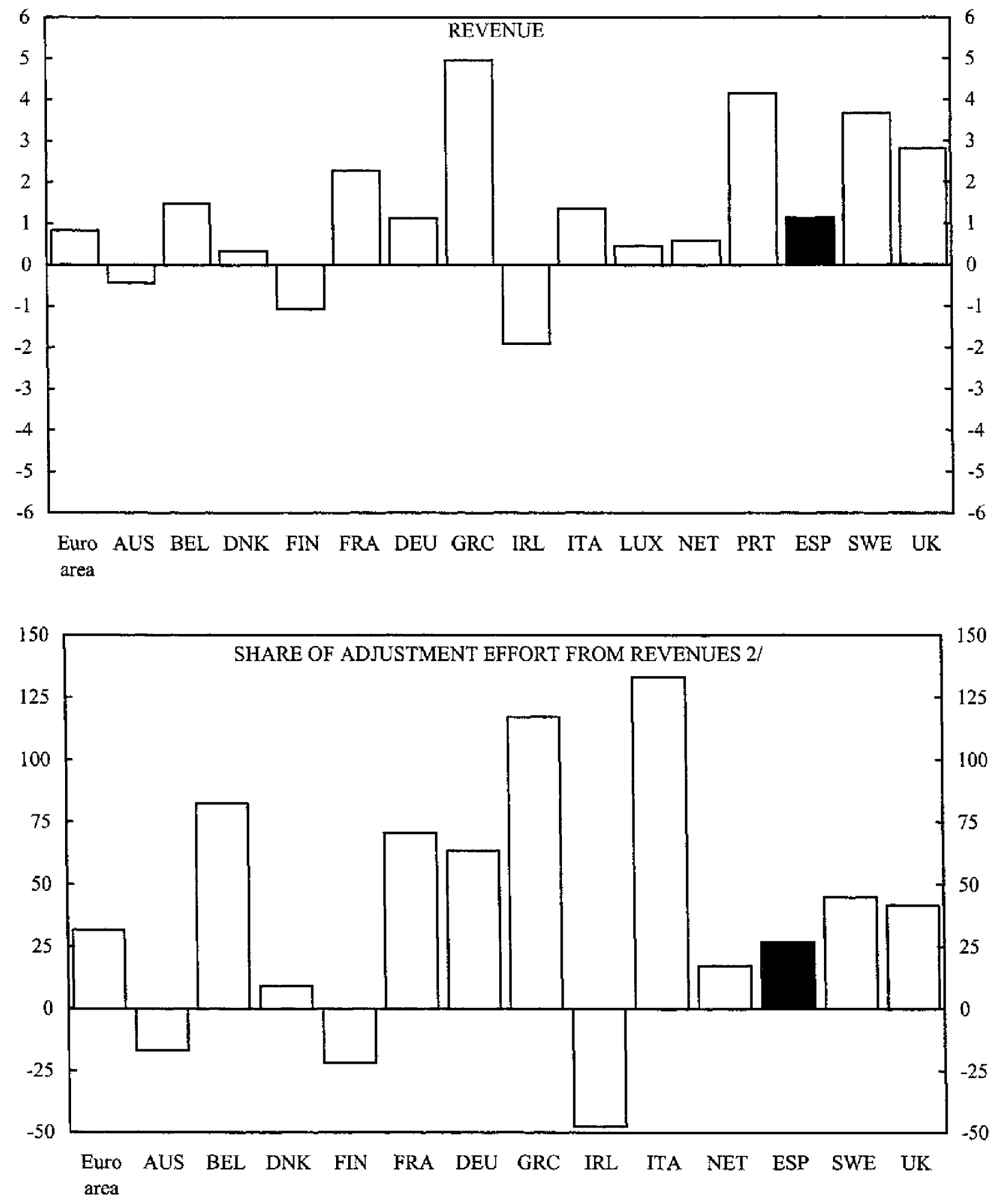

Sources: IMF, World Economic Outlook; and Fund staff estimates.

1/ Euro area figures are unweighted averages.

2/ Change in revenues as a percentage of change in primary balance.

CInternational Monetary Fund. Not for Redistribution 
Figure 3. Selected Countries: Marginal Tax Wedges, 1997

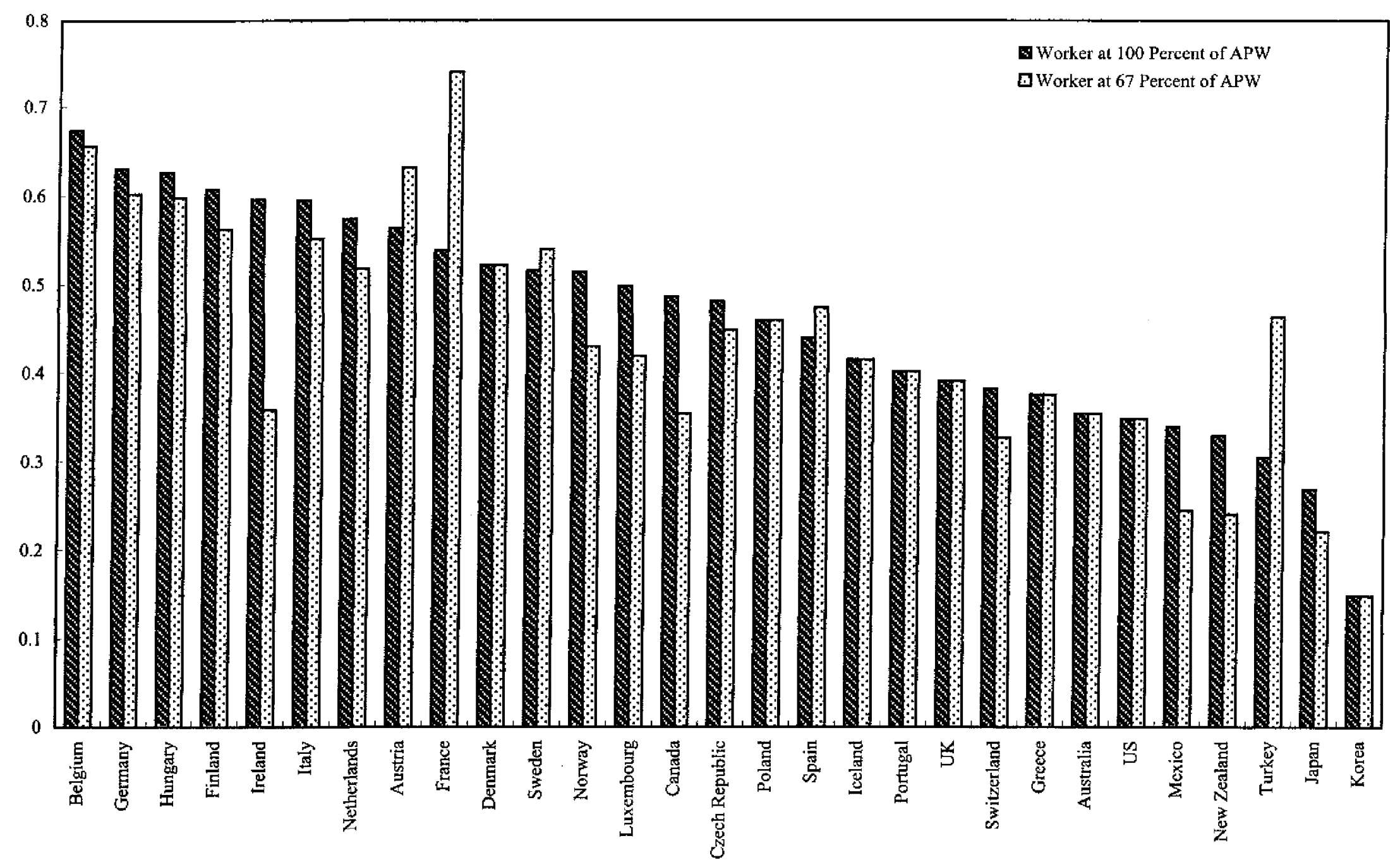

Source: OECD, The Tax/Benefit Position of Employees .

Note: Marginal personal income taxes plus employee and employer social security taxes, as a percentage of gross labor costs.

Striped bar is for an unmarried individual at the income level of the average production worker in each country. Dotted bar is for an unmarried individual at 67 percent of the income level of the average production worker. 
than half of indirect taxes come from the VAT, with most of the balance coming from excise taxes on specific products (such as tobacco, petroleum and alcohol).

10. The expenditure ratio is Spain is also substantially lower than in the rest of the euro zone, standing at about 41 percent of GDP in 1999 compared to an average of nearly 49 percent for the euro area. As with revenues, only Ireland had a lower level of government expenditure than Spain within the euro area (Figure 4). Almost all categories of primary expenditure have been trimmed since 1995, reflecting moderate public sector wage growth (and a decision of the State government to replace only one of every four departing workers), a decline in unemployment compensation because of a sharp drop in the rate of unemployment, and cuts in capital spending. Despite the decline in capital spending, gross fixed capital formation stood at 3.4 percent of GDP in 1999, substantially above the euroarea average. Spain's relatively high capital spending is due in part to the transfers it receives from the European Union, which have averaged about 11/4 percent of GDP on a net basis over the period 1995-99.

11. In 1999 , a little over 40 percent of public expenditure went to public consumptionlargely wages and salaries - and a little over 30 percent to current transfers. An additional 9 percent of expenditure was dedicated to interest payments. Thus, about 80 percent of public expenditure is either nondiscretionary or very difficult to adjust on a sustainable basis without structural reforms. This relatively rigid structure of expenditure means that the burden of any short-term reductions in spending will by necessity tend to fall disproportionately on a relatively narrow portion of the budget, of which capital expenditure constitutes the largest portion.

\section{Decentralization: the experience so far}

12. Over the last quarter century, Spain has made the transition from being one of the most centralized countries in Europe to one whose level of decentralization (measured by the share of the central government in public expenditure) is close to the industrial country average. At the time of General Franco's death in 1975 the central government accounted for some 90 percent of public expenditure. By 1999, this ratio had dropped to a little over 60 percent, about the same as the ratio in federal countries like Germany and the United States (typically around 55-60 percent) and below that in such unitary countries as France (where the central government accounts for about 75-80 percent of public spending). A major impetus to decentralization was the creation, as part of the 1978 Constitution that helped formalize the transition to democracy, of 17 formal regions.

13. Over the past two decades, fiscal decentralization has largely taken the form of devolving additional spending powers to the regional governments, typically without granting them equivalent revenue-raising capacities. This has required regions to receive transfers from the central government to meet their expenditure responsibilities. In recent years debts and deficits for the regional and municipal governments have been contained through a number of mechanisms, the most important of which has been a multiyear agreement spelling out each level of government's contribution to meeting the overall public 
Figure 4. Selected Countries: Public Expenditure, 1999 (In percent of GDP)
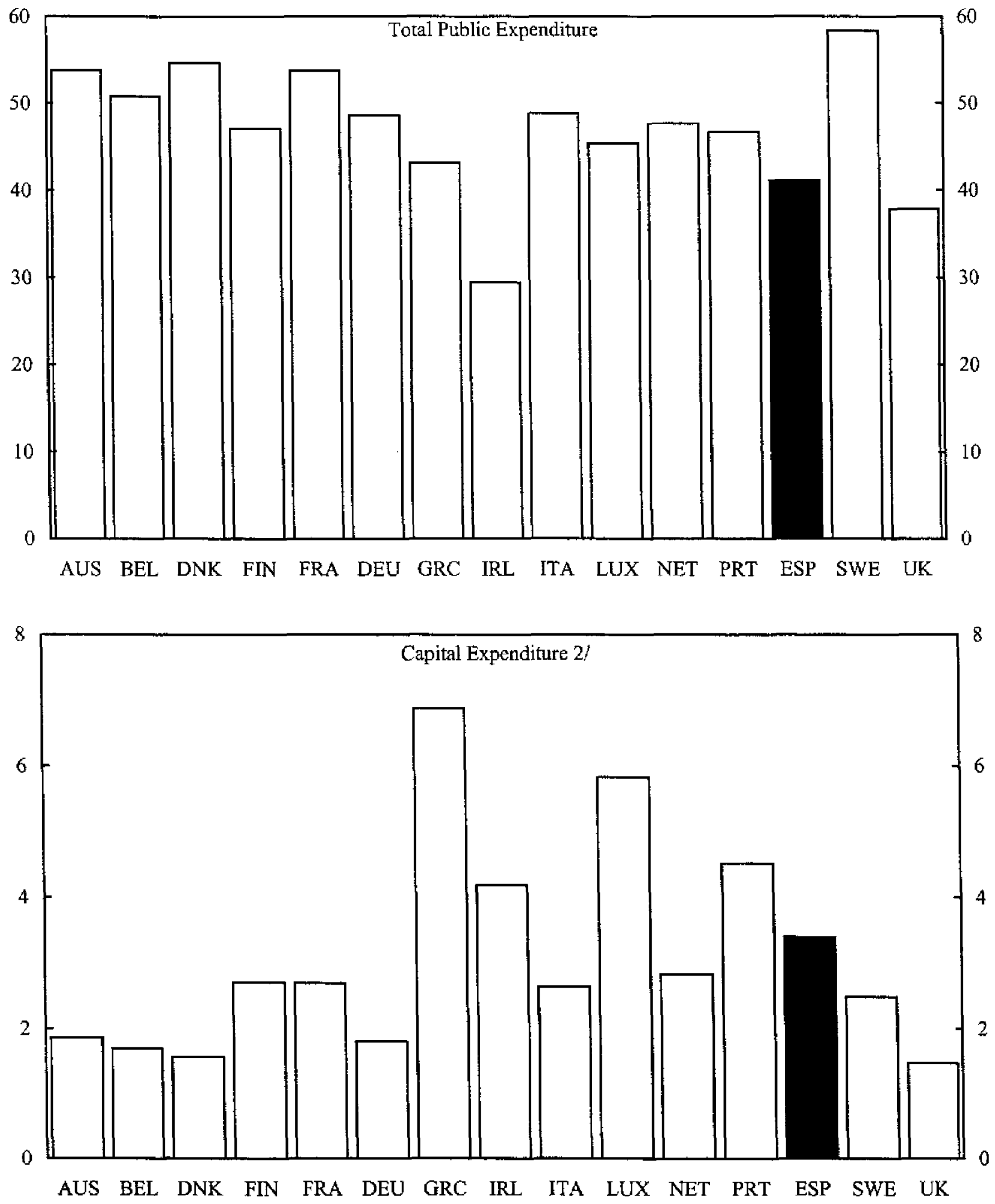

Sources: IMF, World Economic Outlook; and Fund staff estimates.

1/ Euro area figures are unweighted averages.

2/ Excludes capital transfers. 
sector deficit targets established under the Spain's Convergence and Stability Programs. Implementation of the agreement has been coordinated through the Consejo de Politica Fiscal $y$ Financiera (CPFF), which consists of the Ministers of Economy, Finance, and Public Administration, as well as representatives of various regions. The CPFF sets the debt and deficit targets for each level of government, and subsequently for each individual region and municipality. Although there are no penalties for violating the deficit or debt targets established under the agreement, to date the regional and municipal governments as a whole have broadly respected the agreements undertaken within the CPFF.

14. Borrowing by the regions is subject to various legal constraints: approval of the central government is required for all bond issues and foreign currency borrowing, even though these obligations carry no central government guarantee; short-term borrowing can be undertaken only for purposes of liquidity management; long-term debt can be issued only to finance investment expenditure; and debt service cannot be higher than 25 percent of a region's current revenues. The requirement that the central government approve bond issues of regional governments raises the possibility that a region that failed to achieve its deficit targets under the internal stability pact could face financing constraints.

15. Of the 17 regions in Spain, 15 are covered by the so-called "Common Regime" for sharing revenues (see $\mathrm{SM} / 97 / 76,3 / 5 / 97$ for details). Under this regime, regional governments have access to the following revenue sources:

- taxes on wealth, inheritances, property transactions, legal acts and gambling (the "ceded taxes");

- user charges and fees for services;

- a 30 percent share of personal income tax revenues collected in their jurisdictions; and

- a share of overall tax revenues collected by the central government (the Participación en los Ingresos del Estado, or PIE).

Several important modifications to the system were introduced in 1997. First, the PIE was altered to rise in line with national GDP rather than with national tax revenues. Second, regions were given the right to vary (within limits) the rates and deductions on the personal income tax in their jurisdictions. While to date no region has chosen to modify marginal tax rates, some have elected to make adjustments to certain deductions under the tax. Third, a guarantee scheme was introduced under which the central government would ensure that each region's revenues from its share of the personal income tax will rise at least as fast as national GDP. Of the 15 common regime regions, three (Andaluciá, Castilla la Mancha and Extremadura) refused to accept the innovations of the 1997 financing arrangement. These three regions continue to receive their PIE based on the old formula (with no guarantee that it will grow in line with GDP). In addition, these regions do not have the right to vary the tax 
rate on the personal income tax or to collect the ceded taxes. The current regime was introduced for a five-year period, and thus will expire at the end of 2001.

16. The two regions not covered by the Common Regime are the Basque Country and Navarra. For historical reasons, these regions have their own personal and corporate income taxes, and collect most tax revenues independently of the central government. Most expenditure responsibilities have also been devolved to these regions. The two regions provide an annual payment to the State government to cover their shares of expenses that are borne nationally - such as defense and foreign affairs - with the share determined by the ratio of regional to national GDP.

17. Expenditure responsibilities devolved to common regime regions are less extensive, but have grown relatively rapidly, and regional governments now account for about onefourth of total public sector spending, compared to less than 5 percent in the early $1980 \mathrm{~s}$. Among the most important categories of expenditure transferred to the regions are social services, active labor market policies, and some infrastructure investments. Responsibility for health care and primary and secondary education has been transferred to a number of regions, and all regions will eventually be responsible for these expenditures.

\section{Challenges for the Medium and Long Term}

18. The section reviews three major challenges to the public finances in Spain (in common with many other countries) in the medium and long term: dealing with the impact of population aging, especially on social security expenditure; developing a permanent arrangement for the financing of regional and municipal governments; and maintaining and enhancing an environment supportive of economic growth, particularly in a context of significant disparities in per capita incomes across regions. Although these challenges are assessed separately, it is worth emphasizing that they are in fact closely linked. For example, the impact of demographic changes on pension finances could be offset to some extent by policies that increase Spain's low labor force participation rate. At the same time, higher participation and employment in relatively poorer regions could also help address regional income disparities in Spain. This, in turn, could ease the task of developing a framework for fiscal federalism that gives regions greater autonomy over revenues without compromising the solidarity of the system. This raises the prospect that a successful resolution to one set of challenges could generate a virtuous circle that contributes to resolving the others, as well.

\section{The demographic transition}

19. As in most industrial countries, the coming demographic transition will put considerable pressure on public spending in Spain. As the baby boom arrived somewhat later in Spain than in other industrial countries, the impact of population aging on the public finances will likewise occur later in Spain than elsewhere in Europe. Nevertheless, by some estimates the dependency ratio (defined as the number of individuals aged 65 and above per individual aged 16-64) will nearly double over the next 50 years, from a present 0.5 to about 0.9 by the middle of the next century. 
20. To estimate the impact of the coming demographic shock on the public finances, the staff conducted a simulation of pension developments covering through the year 2050 (see Appendix I). Obviously, forecasting fiscal developments 50 years into the future is difficult, particularly as small changes in initial assumptions-for example, about productivity and wage growth - can accumulate into large differences in outcomes a half century later. Thus, the point of the simulation is not to reduce the uncertainty about future pension

developments, but rather to focus attention on the tradeoffs among different policy options under uncertainty.

21. On stylized assumptions comparable with those used in many more detailed analyses ${ }^{3}$ the simulations find a substantial deterioration in the public sector expenditure ratio, based on current policies. Specifically, social security contributions are projected to remain essentially constant at about $9 \frac{1}{2}$ percent of GDP, while expenditures nearly double, from about 91/4 percent at present to more than 17 percent by the end of the projection period, moving the social security system from its current small cashflow surplus to annual deficits of almost 8 percent of GDP (Table 2). ${ }^{4}$ Deficits begin to emerge around 2015, and build rapidly thereafter. By 2050 , the accumulated deficit of social security is projected to reach about 150 percent of GDP. These baseline assumptions assume no increase in the participation rate for individuals aged 25-54, which remains constant at its present level of about 64 percent. The participation rate for the entire population falls from about 50 percent at present to about 38 percent in 2050, because of population aging. The projections also assume long run annual productivity growth of $1 \frac{1}{2}$ percent. Real wages are assumed to grow in line with productivity, keeping labor's share of national income constant.

22. The simulations assume the remainder of the public sector stays in budgetary balance throughout the projection period. With the nominal stock of debt thus holding constant, the debt ratio (excluding the social security reserve fund) declines steadily. Resulting interest savings are used to gradually reduce the tax ratio rather than to increase expenditures. Of course, population aging and rising per capita incomes will also put pressure on health care

\footnotetext{
${ }^{3}$ For example, see José Herce and Javier Alonso Meseguer, "La reforma de las pensiones ante la revisión del Pacto de Toledo" Caja de Ahorros y Pensiones de Barcelona, Colección de Estudios Económics Number 19 (2000).

${ }^{4}$ These numbers refer to revenues and expenditures related to contributory pensions. They exclude noncontributory pensions and other nonpension benefits, and therefore do not correspond to the balance of the social security system as reported by the Spanish authorities. The decision to present the analysis in terms of the contributory system only was motivated by a desire to concentrate on the financial prospects of the main component of the system.
} 
expenditure, although this would be partially offset by lower spending on education and possibly other programs."

23. An alternative scenario considers the impact on social security finances of a reform that reduces the incidence of early retirement, leading over time to a decline by half of the share of individuals aged 55-64 who are receiving pensions (currently estimated at about 19 percent). While such a reform would have only a moderate impact on the size of the cashflow deficit at the end of the projection period-with the deficit in 2050 declining by about $3 / 4$ percent of GDP — such a reform would slow the emergence of the deficits by several years (Table 2a). As a result, the accumulated deficit of the pension fund at 2050 would be only about half of its level under the baseline scenario. The improvement in pension finances arises from two factors. First, with retirement delayed, there are fewer retirees to receive pensions each year, relative to the baseline scenario. Second, with more workers (again compared to the baseline scenario) output grows more rapidly, reducing pension expenditures as a share of GDP. Because labor income growth is tied to output growth, pension revenues as a share of GDP do not increase in the alternative scenario (relative to the baseline), although of course their nominal value would be greater.

24. A final alternative scenario assumes not only a pension reform to delay early retirement but also a series of labor market reforms that succeed over time in raising the participation rate in Spain to the current EU average of about 75 percent (Table 2b). Such a reform would have a dramatic affect on the finances of the pension system. In particular, the emergence of cashflow deficits would be delayed by about 15 years compared to the baseline scenario, and the accumulated balance of the pension system would remain positive beyond the end of the projection period. Nevertheless, the system would still generate a significant cashflow deficit, on the order of 5 percent of GDP, by 2050. Compared to the first alternative scenario, the improvement in finances comes entirely from the effect on output of a substantial increase in labor supply.

25. Under the Maastricht system, higher pension expenditure cannot lead to an unsustainable fiscal position, because the deficit limits under the system prevent this. Thus, while the three scenarios presented above assume that the non-social security balance of the public sector is equal to zero, in practice the remainder of the public sector would be required to run a significant surplus in the later years, in order to at least partially offset the pension deficit. Under the most optimistic of the three scenarios, much of the necessary surplus could be achieved simply by maintaining the tax ratio constant at its 1999 level, rather than allowing it to drop by 3 percent of GDP between 2002 and 2050 in response to a decline in interest expenditure. Nevertheless, nonpension expenditure would still need to fall by close to 2 percent of GDP to keep the overall public sector in balance. Given that it may prove

\footnotetext{
${ }^{5}$ An analysis undertaken for last year's Article IV consultation estimated that health care expenditure in Spain could increase by about 31/2 percent of GDP by 2050 because of these factors (see SM/99/138,6/16/99).
} 
difficult to limit real growth in some categories of expenditure like wages and especially health care (demand for which will likely rise sharply in response to income growth), the burden of achieving the required adjustment in State spending may fall disproportionately on other items, notably capital expenditure, that are more easily adjusted.

26. Alternatively, the increase in pension expenditure could be met while maintaining the pay-as-you-go character of the present pension system simply by increasing payroll taxes as needed to maintain balance (in a cashflow sense) in the social security accounts. Based on the mission's projections, achieving balance in the social security accounts in the year 2050 would require an across-the-board increase in social security taxes of 50 percent relative to their current level under Scenario 2B. Had such a contribution rate applied in 1997, the average tax wedge for such a worker would have exceeded 50 percent, making it among the highest such rates in Europe.

27. Thus, it would appear that a key component of policies to address the demographic shock must lie in reforms of pension entitlements over time. A number of approaches are possible, and consultations with the social partners would be valuable in designing specifics. Nevertheless, the broad priorities for such reforms are clear. Possible measures would include reforms to ensure that access to early retirement is not widened from its current levels; steps to encourage older workers to remain in the labor force; a lengthening of the reference period for calculating the pension base for retirees; and more generally ensuring a closer link between a worker's pension contributions and benefits. Measures to stimulate the growth of private pension plans could also play a role, including by making reductions in the generosity of the public system more feasible. Futher labor market reforms could also play a supportive role by raising the participation rate and reducing the rate of unemployment beyond the level assumed in the simulations.

28. As noted at the outset of this section, projections about the behavior of any variable 50 years in the future are subject to considerable uncertainty. This is all the more the case when the variable being forecasted is the balance of the social security system, which depends on assumptions about labor supply, wage, population and productivity growth, and numerous other factors. Accordingly, it is natural to consider the implications of the policy options being outlined here in the very likely case that the pension scenario turns out widely off the mark, say because the demographic assumptions are unduly pessimistic or productivity growth turns out to be much greater than expected. The reforms advocated in this section-specifically, encouraging workers to remain in the labor force, linking pension benefits more closely to contributions, and accumulating a small pension reserve fundwould increase labor force participation, create room for higher capital expenditure (or reductions in the tax wedge) within existing levels of public spending, and establish a small downpayment against an increase in expenditure that-even if it is overestimated in the simulations - appears inevitable. The accumulation of a pension surplus could also have important countercyclical effects in the context of current strong rates of output growth. The benefits of such policies, even in the absence of a demographic shock, are clear. Thus, the risks are assymetrical: there are benefits to implementing the policies being advocated even if 
the scenario is wrong, and serious risks to ignoring them if the scenario turns out to be even mildly accurate.

\section{Key issues in decentralization}

29. As noted above, the current agreement covering regional financial arrangments is due to expire at the end of next year. With the transfer of expenditure responsibilities to the regional governments now largely complete, the upcoming renewal of the agreement marks an ideal opportunity to negotiate a more permanent arrangement that adds greater stability to the system and responds to some of its current shortcomings.

30. Although to date regional governments have by and large complied with their obligations to reduce their deficits in line with the targets established by the CPFF, there may be a risk that with Spain now having entered into Stage 3 of monetary union, and with the overall public sector deficit well below 3 percent limit established by the Stability and Growth Pact, the commitment to expenditure restraint of some regional governments may begin to flag. While regions that violate their deficit targets can lose access to market financing, this is at best an imperfect instrument to ensure fiscal discipline, as such regions would continue to have access to bank lending. There are no financial penalties associated with failure to achieve the CPFF targets.

31. In addition, incentives for fiscal restraint among regional governments are weakened by the fact that while they have a great deal of autonomy over expenditure, a substantial portion of their revenues comes in the form of transfers from the State government. In 1999 , more than half of the current revenues of regional governments came from transfers from the State government (primarily the first 15 percent share of income taxes collected in their jurisdictions--over which they have no taxing powers-and the PIE). An additional onesixth of their current revenues came from the regional personal income tax (that is, the second 15 percent share of personal income taxes), although the importance of this source varies by region depending on per capita income. While regions that have accepted the 1997 reform of the financing system have the right to vary marginal rates for this tax, in practice none have done so. Moreover, the fact that the regions receive a guarantee from the State that the resources from this "regional income tax" will always grow at least as fast as national GDP means that, to a large extent, it also functions as a transfer from the central government. This implies that regional governments can garner the political benefits of increasing their expenditures without paying the political price of having to raise taxes to do so.

32. The large share of revenues that are derived from personal income tax collections has the potential to substantially increase the volatility of regional government financial resources, thus complicating the budgetary process. Over the period $1986-95$ the standard deviation of the growth rate of household incomes (pre-tax) across regions was significantly higher than that for either consumption or GDP (Table 3). In addition, the standard deviation of the growth rate of personal income tax receipts across regions is very high, with some tendency for income tax receipts to be more variable in poorer regions than in wealthier ones: the correlation between the standard deviation of the growth rate of personal income taxes 
and per capita income (relative to the national average in 1995) is -0.4 , presumably reflecting the narrow revenue bases of some of the poorer, more agricultural regions.

33. As noted above, the existence of the guarantee scheme on regional tax revenues may weaken the incentive for fiscal consolidation at the regional level. In addition, the guarantee significantly complicates the tax reform process, as it requires the State government to absorb the burden of any decline in the tax ratio exclusively from its own resources. This may constrain the scope for further tax reform in the medium term.

34. Turning to the expenditure side, while decentralization of expenditures has the potential to increase the efficiency of public spending by allowing it to be more responsive to local needs and preferences, there is also a risk that spending efficiency could decline because of wasteful duplication of services across regions or loss of economies of scale. One area potentially at issue is health care, where spending has already been devolved to seven autonomous communities (representing about 60 percent of the population) and is to be fully devolved by the end of 2001 . With health expenditure decentralized, it may prove difficult to coordinate expensive investment projects (for example in new hospitals or advanced equipment) that could most efficiently be shared across regions. A weakening of the monopsony power of the national health system-which has been exploited in the past to bargain for rebates from drug companies, for example - could also lead to an increase in expenditure. However, the fact that pharmaceutical expenditures have grown more slowly in Andalucia, where health spending is controlled by the regional government, than in the regions still under centralized control demonstrates that decentralization need not always result in higher spending.

35. Finally, municipal governments remain highly dependent on revenues from land: in 1997, more than 40 percent of current revenues (excluding transfers) came from taxes on land and real estate, specifically the tax on real estate ( 32 percent of current revenues), the tax on construction ( 6 percent), and the tax on increases in the value of urban land (5 percent). Municipal governments also benefit from sales of their own landholdings (which generate about the same level of resources as the tax on increases in the value of urban land). The heavy reliance of muncipal finances on revenues associated with land creates a powerful incentive for local governments to restrict the supply of land for urban development in order to increase its price and their revenues.

36. As in the case of reforms to the pension system, the approaches ultimately adopted to resolve these shortcomings could usefully result from a consensus-building approach among the State, regional and municipal governments. However, again, the broad outlines of potential reforms are clear. First, there is a need to ensure that regional and municipal governments face hard budget constraints, both to ensure that the commitment to fiscal discipline does not weaken and to guarantee that regions that wish to increase their spending levels are forced to pay the political price of increasing their taxes. The introduction of formal penalities for violating budget constraints-and the timely publication of budgetary outturns for lower levels of government-could be one means of achieving this end. Second, consideration should be given to ending the current system of basing revenue transfers in part 
on the share of personal income taxes collected in a region and replacing it with a more stable base such as the Value-Added Tax. Such a reform would reduce the variability of regional revenue sources, and could also ensure a more progressive distribution of revenues. More generally, and in line with the aim of making regions that wish to increase their spending increase their tax revenues, as well, consideration should be given to measures that would transfer greater revenue raising authority to the regions and reduce the extent to which their incomes represent pure transfers. One possibility would be to transfer to the regions responsibility for the Impuestos Especiales that apply to specific products. However, a key challenge will be to marry greater revenue-raising responsibilities at a regional level with solidarity concerns at a national level. Replacing the current guarantee scheme with greater regional revenue-raising autonomy could be a first step to ensuring that the burden of adjusting expenditure to match revenue declines does not fall exclusively on the State budget, but futher mechanisms (perbaps in the context of a more binding internal stability pact) could also be necessary.

37. On the expenditure side, measures will be necessary to ensure that further decentralization of expenditure does not result in a decrease in public sector efficiency. For some areas of expenditure, such as health care, it may be possible to introduce a system of budgetary transfers across regions when residents of one region obtain services in another. More generally, it will be necessary to create mechanisms that encourage regions to spend optimally when there are spillover effects across regions, and to prevent free riding by regions that might wish to take advantage of services that are available in neighboring regions without paying their fair share of the associated expenses.

38. Finally, measures will be necessary to reduce the reliance of municipalities on revenues from property, which has introduced serious distortions in land and labor markets. The package of structural reform measures introduced by the authorities in June of this year has already made a first step towards resolving this problem by reducing the scope for discretion in classifying land as eligible for urban development. Additional measures could provide municipalities with a broader array of revenue sources, perhaps through the devolution of some taxes now collected at a regional or national level. However, it is worth bearing in mind that some municipalities in Spain are very small-with populations of only a few hundred-and may therefore lack the capacity to administer complicated taxes. In addition, it should be noted that property-related revenues are an important source of income for municipalities in much of the world, and are likely to remain so in Spain even after a further reform of local government finances.

\section{Supporting growth and employment in the coming decade}

39. There is considerable evidence that Spain is among the countries where fiscal contraction has had a positive effect on output in recent years. However, much of the positive impact of previous fiscal consolidation on growth was likely associated with meeting the Maastricht debt and deficit criteria for Stage 3 of monetary union, and the resultant effects on confidence and interest rates--effects which have essentially run their course. But, in any 
case, with nominal and structural fiscal balance now in sight, the impact of fiscal consolidation-whether expansionary or contractionary-may now be relatively small.

40. Under these circumstances, further fiscal efforts to support employment and output growth are more likely to arise from changes in the level and mix of revenues and expenditures than from changes in the size of the deficit itself. As noted above, the tax wedge in Spain is moderate, at least by European standards. Nevertheless, further reductions in marginal tax rates and modifications to the base for the personal income tax are both desirable and planned, with likely beneficial effects on labor supply and income. While recent reforms have concentrated on the personal income tax-or on social security contribution rates for selected classes of workers-other types of reforms could also be valuable. For example, the existence of a fixed minimum contribution to the social security system means that the marginal tax wedge for the unemployed or very low paid workers is higher than the average tax wedge. Eliminating the minimum contribution could generate an increase in labor supply and help move workers out of the underground economy (a process that is likely already underway). Of course, further labor market reforms to increase participation would have similar effects on output and employment. In addition, pension reforms that reduced the need for future tax increases would be beneficial for labor supply and output.

41. Another key link is that between the composition and design of expenditure programs and employment and output growth. One dimension of this is infrastructure expenditure, as the authorities have identified infrastructure shortages as being a key factor constraining the growth of potential output. Thus, they plan to increase capital investment from its current level of 31/2 percent of GDP to 4 percent-about twice the euro-area average-over the coming years. Maintaining this level of capital expenditure in the face of coming demographic pressures on current spending may prove difficult. In this respect, and as noted earlier, steps could be required to ensure that expenditure adjustment does not fall disproportionately on capital spending.

42. In recent years, a number of EU countries - for example, Finland, the Netherlands, and the United Kingdom-have adopted medium-term expenditure frameworks. Although the motivation for adopting these mechanisms has varied from country to country, in general all sought at least in part to ensure that the burden of needed fiscal adjustment does not fall disproportionately on capital expenditure or other budgetary items that are relatively easy to adjust in the short run but rather is allocated in a strategic manner that spreads the impact of spending cuts optimally. Frequently, they have also been introduced as a means to ensure that expenditure policies allow room for reductions in tax rates, as well as fiscal consolidation goals. Experience with these frameworks suggests that to function effectively, they need to be based on realistic macroeconomic forecasts, as building in excessive "margin for error" through unduly pessimistic forecasts tends to reduce the rigor of the exercise. Experience has also shown that a two- to three-year time horizon is typically optimal: beyond three years, the inaccuracy of macroeconomic forecasts and the difficulty in predicting new demands on expenditure makes the spending plans of limited value. In addition, it is important to develop understandings at the outset about how revenue windfalls will be dealt with. Otherwise, there 
is a risk that higher than expected revenues could be dedicated to tax cuts or higher spending, imparting a procyclical bias to fiscal policy. Appendix II reviews the experience with medium-term budget exercises in greater detail.

43. In the case of Spain, the development of an effective medium-term expenditure framework stands to benefit greatly from the experience in other countries, including its neighbours in the European Union. The overall goals, doubtless, would be closely aligned with those cited above: the need to complete fiscal consolidation without sacrificing infrastructure spending, and over time to achieve a further decline in the overall tax burden, particularly on labor income. And in designing a framework to achieve these goals, several of the potential lessons from experience identified above would appear relevant. As to the particular challenges in this case, Spain's rapid growth experience and its decentralized fiscal structure need to be closely borne in mind. The decision on prudent but not overly conservative growth assumptions is clearly a difficult one, and in this connection close attention would need to be given to agreement ex ante on how to avoid imparting a procyclial bias to policy. Furthermore, a continuing and effective consensus with lower levels of government would be critical-both to ensure consistency with overall national fiscal goals, and to provide checks and balances that avoid tax and expenditure levels creeping up unduly, for any given deficit or surplus objective, due to initiatives at lower levels of government.

44. A second dimension through which expenditure policy can contribute to the growth of output and employment is to ensure that the design of transfer programs encourages integration into the labor market. The authorities have already indicated an intention to tighten the enforcement of regulations requiring individuals receiving unemployment benefits to enter into training programs or accept suitable job offers provided to them through the national employment services. While unemployment benefits are not unusually high, the very large severance payments received by workers on permanent contracts-some 30 months' pay for a core worker with 20 years' tenure whose dismissal was ruled unjustified-may discourage reintegration. ${ }^{6}$ In addition, unemployment benefits are received for a relatively long period-up to two years, depending on the length of time an individual has contributed to the insurance system, with extensions of 18-30 months for those with dependents-which also discourages the unemployed from moving back into the labor force quickly, before their skills have eroded. ${ }^{7}$ (At the same time, it is worth noting that because of the contributory nature of the benefit, only about half of the unemployed actually receive unemployment compensation). Finally, programs like the Subsidio para Eventuales Agricolas that provide financial benefits to individuals involved in temporary agricultural

\footnotetext{
${ }^{6}$ Comparable figures are 18 months' pay in Germany and 15 months' pay in France, for example.

${ }^{7}$ The length of the extension depends on the amount of time the individual has contributed to the social security system. In addition, workers who are over 45 years of age and have no dependents are eligible for a six-month extension of benefits.
} 
employment in Andalucía and Extremadura may also discourage underemployed workers from a fuller integration into the labor market.

45. A third dimension is the interaction of expenditure policies with regional economic performance. With the system of regional financing now under review, it is particularly timely to ask how expenditure policies can best address imbalances in regional growth and incomes, for example through a more focussed allocation of public capital expenditure and/or better designed training and transfer programs.

46. There is no doubt that substantial regional disparities exist in Spain: in 1998, the per capita value added of the poorest region in Spain, Andalucia, was less than half that of the richest, Baleares (Table 4). Moreover, these disparities have shown considerable persistance: the five richest regions in 1985 (Baleares, Madrid, Cataluña, the Basque provinces, and Navarra) remained the five richest in 1998, and the five poorest regions in 1985 (Extremadura, Andalucia, Castilla-La Mancha, Galicia, and Murcia) remained the five poorest in 1998. Moreover, the ratio of value added per capita in the five richest to the five poorest held virtually constant between 1985 and 1999 at 1.7 , and the standard deviation of regional per capita value added (as a percentage of the national average) in 1998 was essentially unchanged from its level in 1985 . While Spain is not the only European country to confront regional inequalities, the data do suggest that the problem may be more severe in Spain than in some of its neighbors. Gini indices suggest that regional inequality in Spain is lower than in Italy, and on a par with that in France, but greater than in Belgium, Germany, the Netherlands, Portugal and the United Kingdom. ${ }^{8}$

47. Some of the regional variation in per capita output in Spain reflects large and persistent differences in unemployment rates across regions: although the five richest regions in Spain in 1985 in terms of value added per worker remained the richest in 1998, and four of the five poorest regions so-defined in 1985 remained among the five poorest in 1998, the ratio of average value added per worker in the five richest compared to the five poorest has been both consistently lower than the per capita ratio, and has declined over time, from 1.5 in 1985 to 1.3 in 1998 (Table 5). The standard deviation of value added per worker across regions is also lower than that of value added per capita. In addition, a number of authors have documented a tendency for convergence in value added per capita in Spanish regions over a longer time horizon than that considered here, although they have found that the rate of such convergence has declined over the last 20 years or so. ${ }^{9}$

\footnotetext{
${ }^{8}$ J.M. Esteban, "La desigualidad interregional en Europa y en España: descripción y análisis" in Esteban and Vives, eds. Crecimiento y Convergencia Regional en España y Europa (Barcelona: Instituto de Análisis Económico, 1994).

${ }^{9}$ See, for example, B. Garcia-Greciano and J.L. Raymond, "Las Disparidades Regionales y La Hipótesis de Convergencia: una Revisión" in Papeles de Economia Española (Madrid:
} 
48. The persistence of very large differences in unemployment rates across regions is puzzling, as interregional migration and shifts in wage rates should over time have led to a covergence in such rates. Previous studies ${ }^{10}$ have jdentified a relatively centralized wage bargaining system as part of the explanation why wages do not fall sufficiently in high unemployment regions to reduce the jobless rate. A shortage of rental housing, the prevalence of temporary employment contracts, and inadequate diffusion of information about job openings have also been cited as contributing to persistent differences in unemployment rates across regions.

49. However, to date relatively little attention bas been directed to the role of public and private capital in this connection. Even if labor does not move across regions, private capital flows ought over time to redress differences in unemployment rates and generate convergence in real incomes more generally, provided the public authorities ensure adequate provision of intrastructure and other public goods. A background study for this selected issues paper (see Appendix III) addresses these issues in detail, looking at long-run tendencies in investment across regions as well as the short-run response of capital to regional shocks.

50. The results of the study suggest that in the period since 1970 private capital has tended to flow to areas where it is relatively scarce, and where the returns to it are relatively high. As a result, there has been a tendency-albeit gradual and inconsistent-for convergence in the ratio of private capital to labor across regions. By contrast, there has been relatively little tendency toward convergence in the ratios of public and human capital to labor: those regions with relatively low endowments of these variables in 1970 continued to have below average levels of them a quarter-century later. The fact that private capital has moved only gradually from capital rich to capital poor regions, while there has been only a limited tendency for public and human capital to locate in areas where it has historically been in relatively short supply, explains the relatively slow convergence of per capita incomes across regions in Spain. Moreover, the study finds that while private capital does respond to differences in the rate of return to private investment across regions, there has been no tendency for private capital to move to regions with relatively high unemployment rates. The reason is that rates of return on private capital by region are essentially unrelated to regional unemployment rates. Thus, the failure of private capital flows to resolve disparities in regional unemployment rates cannot be attributed to capital market failures.

51. In addition, the study finds that differences in rates of return to private investment are primarily accounted for by differences in the stock of private capital per worker across

Fundación de las Cajas de Ahorros Confederadas para la Investigación Económica y Social, 1999).

${ }^{10}$ For example, Paolo Mauro, Eswar Prasad and Antonio Spilimbergo, Perspectives on Regional Unemployment in Europe, IMF Occasional Paper No. 177 (1999). 
regions. In particular, differences in public and human capital per worker have only a limited impact on the rate of return to private capital. This finding suggests that the scope for using public capital investment or policies to encourage the acquisition of human capital as a means of stimulating private investment in high unemployment regions is at best limited.

52. Despite these findings it is clear that public investment does have a role to play in supporting output growth. An additional background study for this selected issues paper (Appendix IV) investigates empirically the role of public capital in the production process in Spain. It finds that public investment can play a significant role in reducing inefficiencies in production and raising output, for example, by eliminating bottlenecks caused by a lack of infrastructure. These results would argue for a well-targeted approach to investment that seeks to relieve specific shortfalls in public capital and remove impediments to growth.

53. Nevertheless, relying on public capital alone as a device to leverage greater investment in human and private physical capital is unlikely to lead to a sharp reduction in regional inequalities in the near future. In addition to public investment, measures to encourage the development of human capital-such as improved training for workers and the unemployed - and to ensure access to financing for entrepreneurs in relatively disadvantaged regions will be key. In addition, reforms that encourage labor mobility and employment growth directly, such as eliminating rigidities in rental housing markets, further reducing dismissal costs, and improving the flow across regions of information about job openings can also help address disparities in per capita incomes.

54. Finally, the social partners have a role to play by maintaining their commitment to keep wage growth under control: recent experience in Spain has shown that household income rises more rapidly when average wages grow more slowly, because of the beneficial impact of wage moderation on employment. Measures to increase the flexibility of the wage bargaining system also are key.

\section{Concluding Remarks}

55. The previous section reviewed three different medium- and long-term challenges to the public finances: dealing with the coming demographic shock; enhancing the regulations governing fiscal federalism; and stimulating growth and employment. Although these topics appear to be distinct, finding the right mix of policy options to respond to them is complicated, because they are in fact closely interrelated. For example, while an increase in payroll taxes could help resolve coming problems in the social security system, a rise in the marginal tax wedge could slow employment growth, with negative implications for redressing imbalances in incomes across regions. Meanwhile, success in reducing disparities in regional unemployment rates could make easier the task of developing a regional financing scheme that both assigns regions a greater role in generating their own revenues and ensures that each region has sufficient resources to provide a minimum level of services to its inhabitants. 
56. Fortunately, there is considerable overlap in the policy prescriptions outlined in the above sections. While establishing a reserve fund for the pension system will help forestall the emergence of cashflow deficits, the real key is entitlement reforms that will slow the growth of spending and encourage labor force participation by tying benefits more closely to contributions. Greater participation is also the key to reducing regional inequalities and fostering further output growth. While higher public capital investment will clearly have a role to play in eliminating bottlenecks and stimulating output, the evidence suggests that employment growth, combined with greater access to financing for entrepreneurs and increased spending on training and education, are perhaps even more essential. And, as noted above, reducing regional disparities can help ensure that a move to greater regional revenue autonomy does not result in a lack of solidarity across regions. In addition, measures to reduce the reliance of municipalities on property revenues can belp remove rigidities in housing and labor markets, encouraging labor mobility and regional income convergence.

57. As welcome as the overlap in policy prescriptions is, it can introduce its own complications to the process. Specifically, because policies designed to address potential problems in one area will have important repurcussions for other areas, developing a package of measures simultaneously capable of meeting the coming challenges and satisfying all interested parties may prove difficult. Experience demonstrates that the central government authorities, the regional and municipal governments, and the social partners can work together in the spirit of compromise so that the success Spain has achieved in meeting the challenges of qualifying for Stage 3 of monetary union can be extended to meet the new set of challenges it confront. 
Table 1. Spain: Public Sector Fiscal Outturn, 1995-2000

\begin{tabular}{|c|c|c|c|c|c|c|}
\hline & 1995 & 1996 & 1997 & 1998 & 1999 & $\begin{array}{l}2000 \\
\text { proj. }\end{array}$ \\
\hline & \multicolumn{6}{|c|}{ (in percent of GDP) } \\
\hline Total revenues & 38.8 & 39.2 & 39.4 & 39.4 & 39.8 & 40.1 \\
\hline Indirect taxes & 10.1 & 10.2 & 10.5 & 11.1 & 11.6 & 12.1 \\
\hline Direct taxes & 10.1 & 10.3 & 10.5 & 10.2 & 10.2 & 10.3 \\
\hline Social security contributions & 13.0 & 13.2 & 13.1 & 13.1 & 13.1 & 13.0 \\
\hline Other revenues & 5.5 & 5.6 & 5.3 & 5.0 & 4.8 & 4.8 \\
\hline Current expenditures & 39.2 & 39.1 & 37.6 & 36.8 & 35.6 & 35.2 \\
\hline Public consumption & 18.1 & 18.0 & 17.6 & 17.2 & 17.0 & 16.8 \\
\hline Current transfers & 13.9 & 13.8 & 13.3 & 12.9 & 12.5 & 12.3 \\
\hline Interest payments & 5.2 & 5.3 & 4.8 & 4.3 & 3.6 & 3.5 \\
\hline Other current expenditures & 2.0 & 2.0 & 2.0 & 2.4 & 2.4 & 2.5 \\
\hline Current balance & -0.4 & 0.2 & 1.8 & 2.5 & 4.2 & 5.0 \\
\hline Gross fixed capital formation & 3.8 & 3.2 & 3.2 & 3.3 & 3.4 & 3.4 \\
\hline Capital transfers and other & 2.4 & 2.0 & 1.8 & 1.8 & 1.9 & 2.0 \\
\hline Primary balance & -1.4 & 0.4 & 1.6 & 1.8 & 2.5 & 3.1 \\
\hline Overall balance & -6.6 & -4.9 & -3.2 & -2.6 & -1.1 & -0.4 \\
\hline State & -5.7 & -3.9 & -2.7 & -2.2 & -1.1 & -0.6 \\
\hline Territorial governments & -0.7 & -0.6 & -0.3 & -0.3 & -0.2 & -0.1 \\
\hline Social security & -0.3 & -0.4 & -0.2 & -0.1 & 0.2 & 0.3 \\
\hline Government debt & 63.1 & 68.1 & 66.7 & 64.6 & 63.3 & 62.8 \\
\hline \multicolumn{7}{|l|}{ Memorandum items: } \\
\hline Structural primary balance $1 /$ & -0.2 & 1.8 & 2.6 & 2.0 & 2.3 & 2.4 \\
\hline Structural balance 1/ & -5.1 & -3.2 & -1.9 & -1.9 & -1.1 & -0.9 \\
\hline Structural expenditure & 44.1 & 42.6 & 41.5 & 41.4 & 40.8 & 40.9 \\
\hline Structural revenue & 38.9 & 39.5 & 39.6 & 39.4 & 39.8 & 40.0 \\
\hline
\end{tabular}

Sources: Cuentas Financieras , Bank of Spain; Intervencion General de la Administracion del Estado ; and staff projections.

1/ Potential output and output gap from staft. For 2000, excludes 0.1 percent of GDP received from the auction of mobile telephone licenses. 
Table 2. Spain: Public Finances, 1998-2050 Baseline Scenario

(It percent of GDP, urless otherwise indicated)

\begin{tabular}{|c|c|c|c|c|c|c|c|c|c|c|c|c|c|c|c|c|c|}
\hline & 1998 & 1999 & 2000 & 2001 & 2002 & 2003 & 2004 & 2005 & 2010 & 2015 & 2020 & 2025 & 2030 & 2035 & 2040 & 2045 & 2050 \\
\hline Revenue & 39.4 & 39.8 & 40.1 & 40.1 & 39.8 & 39.7 & 39.5 & 39.2 & 38.7 & 38.5 & 38.3 & 38.1 & 38.0 & 37.9 & 37.8 & 37.7 & 37.6 \\
\hline Taxes & 21.3 & 21.8 & 22.3 & 22.3 & 22.1 & 21.9 & 21.7 & 21.4 & 20.9 & 20,7 & 20.5 & 20.3 & 20.2 & 20.1 & 20.0 & 19.9 & 19.8 \\
\hline Social Security Contributions & 9.8 & 9.5 & 9.4 & 9.4 & 9,4 & 9.4 & 9.4 & 9.4 & 9.4 & 9.4 & 9.4 & 9.4 & 9.4 & 9.4 & 9.4 & 9.4 & 9.4 \\
\hline Other & 8.4 & 8.5 & 8.4 & 8.4 & 8.4 & 8.4 & 8.4 & 8.4 & 8.4 & 8.4 & 8.4 & 8.4 & 8.4 & 8.4 & 8.4 & 8.4 & 8.4 \\
\hline of which interest receipts & 0.3 & 0.2 & 0.2 & 0.2 & 0.1 & 0.1 & 0.1 & 0.1 & 0.1 & 0.1 & 0.1 & 0.1 & 0.1 & 0.1 & 0.1 & 0.1 & 0.1 \\
\hline Tax ratio $\mathrm{U} /$ & 31.0 & 31.3 & 31.7 & 31.7 & 31.4 & 31.3 & 31.1 & 30.8 & 30.3 & 30.1 & 29.9 & 29.7 & 29.6 & 29.5 & 29.4 & 29.3 & 29.2 \\
\hline Expenditure & 41.9 & 40.9 & 40.6 & 39.9 & 39.3 & 39.0 & 38.7 & 38.2 & 38.0 & 38.3 & 38.6 & 39.4 & 40.6 & 42.1 & 43.8 & 45.3 & 45.4 \\
\hline Primary expenditure & 37.6 & 37.3 & 37.0 & 36.7 & 36.4 & 36.2 & 36.1 & 36.0 & 36.2 & 36.7 & 37,3 & 38.1 & 39.5 & 41.1 & 42.9 & 44.4 & 44.7 \\
\hline of which Social Security & 9.7 & 9.5 & 9.2 & 9.2 & 8.9 & 8.7 & 8.6 & 8.5 & 8.7 & 9.2 & 9.8 & 10.6 & 12.0 & 13.6 & 15.4 & 16.9 & 17.2 \\
\hline Interest payments 2 & 4.3 & 3.6 & 3.5 & 3.2 & 2.9 & 2.8 & 2.6 & 2.3 & 1.8 & 1.6 & 1.4 & 1.2 & 1.1 & 1.0 & 0.9 & 0.8 & 0.7 \\
\hline Overail Balance & -2.6 & -1.1 & $-0,4$ & 0.2 & 0.5 & 0.7 & 0.8 & 0.9 & 0.7 & 0.2 & -0.4 & -1.3 & -2.6 & -4.2 & $-6,0$ & .7 .5 & -7.8 \\
\hline Non-Social Security & -2.7 & -1.2 & -0.5 & 0.0 & 0.0 & 0.0 & 0.0 & 0.0 & 0.0 & 0.0 & 0.0 & 0.0 & 0.0 & 0.0 & 0.0 & 0.0 & 0.0 \\
\hline Social Security $3 /$ & 0.1 & 0.0 & 0.1 & 0.2 & 0.5 & 0.7 & 0.8 & 0.9 & 0.7 & 0.2 & -0.4 & -1.3 & -2.6 & $-4,2$ & -6.0 & -7.5 & -7.8 \\
\hline \multicolumn{18}{|l|}{ Memorandum items } \\
\hline Primary balance & 1.8 & 2.5 & 3.1 & 3.4 & 3.5 & 3.6 & 3.4 & 3.3 & 2.5 & 1.7 & 0.9 & -0.1 & -1.6 & -3.3 & -5.2 & -6.8 & -7.1 \\
\hline Output Gap & 0.7 & 0.0 & -0.7 & -0.8 & -0.6 & -0.5 & 0.2 & 0.0 & 0.0 & 0.0 & 0.0 & 0.0 & 0.0 & 0.0 & 0.0 & 0.0 & 0.0 \\
\hline Non-social security Public Debt & 64.6 & 63.3 & 62.8 & 59.3 & 54.6 & 51.2 & 48.6 & 45.8 & 38.9 & 33,9 & 29.6 & 26.1 & 23.3 & 21.2 & 19.4 & 17.8 & 15.9 \\
\hline Pensionts Reserve Fund 4/ & 0.0 & 0.0 & 0.2 & 0.4 & 0.9 & 1.6 & 2.4 & 3.4 & 8.7 & 12.2 & 13.5 & 11.1 & 2.3 & -16.0 & -46.4 & -90.8 & $-146,7$ \\
\hline
\end{tabular}

Source: Fund staff calculations.

$1 /$ Includes taxes and social security contributions.

$2 /$ Interest is paid only on non-social security debt.

3/ The balance refers to contributive pensions only, and does not correspond to tbe overall balance of the social security system as presented by the Spanish authorities.

4/ Negative value indicates debt accumulation. 
Table 2A. Spain: Public Finances, 1998-2050

Alternative Scenario with Reduction in Early Retirement

(In percent of GDP, unless otherwise indicated)

\begin{tabular}{|c|c|c|c|c|c|c|c|c|c|c|c|c|c|c|c|c|c|}
\hline & 1998 & 1999 & 2000 & 2001 & 2002 & 2003 & 2004 & 2005 & 2010 & 2015 & 2020 & 2025 & 2030 & 2035 & 2040 & 2045 & 2050 \\
\hline Revenue & 39.4 & 39.8 & 40.1 & 40.2 & 39.7 & 39.6 & 39.3 & 39.0 & 38.5 & 38.1 & 37.9 & 37.6 & 37.4 & 37.3 & 37.1 & 37.0 & 36.9 \\
\hline Taxes & 21.3 & 21.8 & 22.3 & 22.3 & 21.9 & 21.8 & $2 \mathrm{1} .5$ & 21.2 & 20.7 & 20.3 & 20.1 & 19.8 & 19.6 & 19.5 & 19.3 & 19.2 & 19.1 \\
\hline Social Security Contributions & 9.8 & 9.5 & 9.4 & 9.4 & 9.4 & 9.4 & 9.4 & 9.4 & 9.4 & 9.4 & 9.4 & 9.4 & 9.4 & 9.4 & 9.4 & 9.4 & 9.4 \\
\hline Other & 8.4 & 8.5 & 8.4 & 8.5 & 8.4 & 8.4 & 8.4 & 8.4 & 8.4 & 8.4 & 8.4 & 8.4 & 8.4 & 8.4 & 8.4 & 8.4 & 8.4 \\
\hline of which interest receipts & 0.3 & 0.2 & 0.2 & 0.2 & 0.1 & 0.1 & 0.1 & 0.1 & 0.1 & 0.1 & 0.1 & 0.1 & 0.1 & 0.1 & 0.1 & 0.1 & 0.1 \\
\hline Tax ratio 1/ & 31.0 & 31.3 & 31.7 & 31.7 & 31.3 & 31.2 & 30.9 & 30.6 & 30.1 & 29.7 & 29.5 & 29.2 & 29.0 & 28.9 & 28.7 & 28.6 & 28.5 \\
\hline Expenditure & 41.9 & 40.9 & 40.6 & 39.6 & 38.9 & 38.5 & 38.0 & 37.4 & 37.1 & 37.3 & 37.6 & 38.2 & 39.3 & 40.7 & 42.4 & 43.7 & 43.8 \\
\hline Primary expenditure & 37.6 & 37.3 & 37.0 & 36.4 & 36.0 & 35.7 & 35.5 & 35.2 & 35.4 & 35.9 & 36.5 & 37.4 & 38.7 & 40.2 & 42.0 & 43.5 & 43.8 \\
\hline of which Social Security & 9.7 & 9.5 & 9.2 & 9.0 & 8.6 & 8.3 & 8.1 & 7.8 & 8.0 & 8.5 & 9.1 & 10,0 & 11.3 & 12.9 & 14.6 & 16.1 & 16.4 \\
\hline Interest payments 2 & 4.3 & 3.6 & 3.5 & 3.2 & 2.9 & 2.8 & 2.5 & 2.2 & 1.7 & 1.4 & 1.1 & 0.8 & 0.7 & 0.5 & 0.3 & 0.2 & 0.1 \\
\hline OYerall Balance & -2.6 & -1.1 & -0.4 & 0.6 & 0.8 & 1.1 & 1.3 & 1.6 & 1.4 & 0.8 & 0.3 & -0.6 & -1.9 & -3.5 & -5.2 & -6.7 & -7.0 \\
\hline Non-Social Security & -2.7 & $\cdot 1.2$ & -0.5 & 0.2 & 0.0 & 0.0 & 0.0 & 0.0 & 0.0 & 0.0 & 0.0 & 0.0 & 0.0 & 0.0 & 0.0 & 0.0 & 0.0 \\
\hline Social Security $3 /$ & 0.1 & 0.0 & 0.1 & 0.4 & 0.8 & 1.1 & 1.3 & 1.6 & 1.4 & 0.8 & 0.3 & -0.6 & -1.9 & -3.5 & -5.2 & -6.7 & .7 .0 \\
\hline \multicolumn{18}{|l|}{ Memorandumitems } \\
\hline Primary balance & 1.8 & 2.5 & 3.1 & 3.8 & 3.8 & 4.1 & 4.0 & 4.0 & 3.0 & 2.1 & 1.3 & 0.2 & -1.3 & -3.1 & -5.0 & -6.6 & -7.0 \\
\hline Output Gap & 0.7 & 0.0 & -0.7 & -0.8 & .0 .6 & -0.5 & .0 .2 & 0.0 & 0.0 & 0.0 & 0.0 & 0.0 & 0.0 & 0.0 & 0.0 & 0.0 & 0.0 \\
\hline Non-social security Public Debt & 64.6 & 63.3 & 62.8 & 58.8 & 53.8 & 50.1 & 47.1 & 44.0 & 35.2 & 28.4 & 22.5 & 17.6 & 13.5 & 9.9 & 6.8 & 3.9 & 1.2 \\
\hline Pensions Reserve Fund 4/ & 0.0 & 0.0 & 0.2 & 0.6 & 1.4 & 2.5 & 3.9 & 5.5 & 14.5 & 22.5 & 28.9 & 32.6 & 30.8 & 20.8 & 0.3 & -32.5 & .74 .8 \\
\hline
\end{tabular}

Source: Fund staff calculations.

$1 /$ Includes taxes and social security contributions.

/ Interest is paid only on non-social security debt

3/ The balance refers to contributive pensions only, und does not comespond to the overall balance of the social security system as presented by the Spanish authorities.

4/ Negative value indicates debt accumulation. 
Table 2B. Spain: Public Finances, 1998-2050

Alternative Scenario with Reduction in Early Retirement and Labor Makket Reforms

(In percent of GDP, unless otherwise indicated)

\begin{tabular}{|c|c|c|c|c|c|c|c|c|c|c|c|c|c|c|c|c|c|}
\hline & 1998 & 1999 & 2000 & 2001 & 2002 & 2003 & 2004 & 2005 & 2010 & 2015 & 2020 & 2025 & 2030 & 2035 & 2040 & 2045 & 2050 \\
\hline Revenue & 39.4 & 39.8 & 40.1 & 40.2 & 39.7 & 39.5 & 39.3 & 38.9 & 38.4 & 38.0 & 37.7 & 37.5 & 37.3 & 37,1 & 37.0 & 36.9 & 36.8 \\
\hline Taxes & 21.3 & 21.8 & 22.3 & 22.3 & 21.9 & 21.8 & 21.5 & 21.2 & 20.6 & 20.2 & 19.9 & 19.7 & 19.5 & 19.4 & 19.2 & 19.1 & 19.0 \\
\hline Social Security Contributions & 9.8 & 9.5 & 9.4 & 9.4 & 9.4 & 9.4 & 9.4 & 9.4 & 9.4 & 9.4 & 9.4 & 9.4 & 9.4 & 9.4 & 9.4 & 9.4 & 9.4 \\
\hline Other & 8.4 & 8.5 & 8.4 & 8.5 & 8.4 & 8.4 & 8.4 & 8.4 & 8.4 & 8.4 & 8.4 & 8.4 & 8.4 & 8.4 & 8.4 & 8.4 & 8.4 \\
\hline of which interest receipts & 0.3 & 0.2 & 0.2 & 0.2 & 0.1 & 0.1 & 0.1 & 0.1 & 0.1 & 0.1 & 0.1 & 0.1 & 0.1 & 0,1 & 0.1 & 0.1 & 0.1 \\
\hline Tax ratio $1 /$ & 31.0 & 31.3 & 31.7 & 31.7 & 31.3 & 31.1 & 30.9 & 30.5 & 30.0 & 29.6 & 29.3 & 29.1 & 28.9 & 28.7 & 28.6 & 28.5 & 28.4 \\
\hline Expenditure & 41.9 & 40.9 & 40.6 & 39.6 & 38.9 & 38.4 & 38.0 & 37.2 & 36.5 & 36.4 & 36.3 & 36.7 & 37.6 & 38.8 & 40.2 & 41.4 & 41.5 \\
\hline Primary expenditure & 37.6 & 37.3 & 37.0 & 36.4 & 36.0 & 35.7 & 35.5 & 35.1 & 34.9 & 35.2 & 35.4 & 36.0 & 37.1 & 38.5 & 40.0 & 41.3 & 41.5 \\
\hline of which Social Security & 9.7 & 9.5 & 9.2 & 9.0 & 8.6 & 8.3 & 8.1 & 7.7 & 7.6 & 7.8 & 8.0 & 8.6 & 9.7 & 11.1 & 12.6 & 13.9 & 14.1 \\
\hline Interest payments 2 & 4.3 & 3.6 & 3.5 & 3.2 & 2.9 & 2.8 & 2.5 & 2.2 & 1.6 & 1.2 & 0.9 & 0.7 & 0.5 & 0.4 & 0.2 & 0.1 & 0.0 \\
\hline Overall Balance & -2.6 & -1.1 & -0.4 & 0.6 & 0,8 & 1.1 & 1.3 & 1.7 & 1.8 & 1.6 & 1.4 & 0.8 & -0.3 & -1.7 & -3.2 & -4.5 & -4.7 \\
\hline Non-Social Security & -2.7 & -1.2 & -0.5 & 0.2 & 0.0 & 0.0 & 0.0 & 0.0 & 0.0 & 0.0 & 0.0 & 0.0 & 0.0 & 0.0 & 0.0 & 0.0 & 0.0 \\
\hline Social Security $3 /$ & 0.1 & 0.0 & 0.1 & 0.4 & 0.8 & 1.1 & 1.3 & 1.7 & 1,8 & 1.6 & 1.4 & 0.8 & -0.3 & -1.7 & -3.2 & -4.5 & -4.7 \\
\hline \multicolumn{18}{|l|}{ Memorandum items } \\
\hline Primary balance & 1.8 & 2.5 & 3.1 & 3.8 & 3.8 & 4.1 & 4.0 & 4.2 & 3.3 & 2.7 & 2,2 & 1.4 & 0.1 & -1.4 & -3.0 & -4.5 & -4.8 \\
\hline Output Gap & 0.7 & 0.0 & -0.7 & -0.8 & -0.6 & -0.5 & 0.2 & 0.0 & 0.0 & 0.0 & 0.0 & 0.0 & 0.0 & 0.0 & 0.0 & 0.0 & 0.0 \\
\hline Non-social security Public Debt & 64.6 & 63.3 & 62.8 & 58.8 & 53.8 & 49.9 & 46.9 & 43,1 & 33.1 & 25.6 & 19.4 & 14.5 & 10.7 & 7.4 & 4.5 & 1.8 & -0.6 \\
\hline Pensions Reserve Fund $4 /$ & 0.0 & 0.0 & 0.2 & 0.6 & 1.4 & 2.5 & 3.9 & 5.8 & 16.6 & 28.2 & 40.7 & 53.2 & 62.7 & 66.8 & 63.8 & 52.6 & 36.0 \\
\hline
\end{tabular}

Source: Fund staff calculations.

$1 /$ Includes taxes and social security contributions

$2 /$ Interest is paid only on non-social security debe.

3/ The balance refers to contributive pensions only, and does not correspond to tbe overall balance of the social security systern as presented by the Spanish authorities.

3/ The balance refers to contributive pensions only. 
Table 3. Spain: Volatility of Tax Bases and Reverues by Region

\begin{tabular}{|c|c|c|c|c|c|c|c|c|c|}
\hline & \multicolumn{2}{|c|}{$\begin{array}{c}\text { GDP } \\
1986-96\end{array}$} & \multicolumn{2}{|c|}{$\begin{array}{c}\text { Private Consumption } \\
1986-96 \\
\end{array}$} & \multicolumn{2}{|c|}{$\begin{array}{c}\text { Pretax Household Income } \\
1986-95 \\
\end{array}$} & \multicolumn{2}{|c|}{$\begin{array}{c}\text { Personal Income Tax } \\
1990-96\end{array}$} & \multirow[t]{2}{*}{$\begin{array}{c}\text { GDP Per Capita in } 1995 \\
\text { (As percent of national average) }\end{array}$} \\
\hline & $\begin{array}{c}\text { Average } \\
\text { Growth Rate }\end{array}$ & $\begin{array}{l}\text { Standard } \\
\text { Deviation }\end{array}$ & $\begin{array}{l}\text { Average } \\
\text { Growth Rate }\end{array}$ & $\begin{array}{l}\text { Standard } \\
\text { Deviation } 1 /\end{array}$ & $\begin{array}{l}\text { Average } \\
\text { Growth Rate }\end{array}$ & $\begin{array}{l}\text { Standard } \\
\text { Deviation }\end{array}$ & $\begin{array}{l}\text { Average } \\
\text { Growth Rate }\end{array}$ & $\begin{array}{l}\text { Standard } \\
\text { Deviation } \\
\end{array}$ & \\
\hline Andalucia & 8.5 & 3.8 & 8.4 & 2.1 & 9.4 & 3.8 & 6.9 & 3.5 & 74.3 \\
\hline Aragón & 8.1 & 3.3 & 7.9 & 1.6 & 9.0 & 3.8 & 6.1 & 3.8 & $113.8^{\circ}$ \\
\hline Asturias & 7.0 & 2.5 & 7.6 & 1.5 & 8.0 & 4.0 & 6.5 & 2.9 & 91.3 \\
\hline Baleares & 8.8 & 2.8 & 7.9 & 1.1 & 9.4 & 3.4 & 8.1 & 1.9 & 136.8 \\
\hline Canarias & 8.9 & 2.8 & 8.8 & 1.6 & 9.6 & 3.2 & 8.9 & 2.3 & 92.8 \\
\hline Cantabria & 8.4 & 4.0 & 8.4 & 1.8 & 8.3 & 3.7 & 5.6 & 2.5 & 97.2 \\
\hline Castilla la Mancha & 8.9 & 4.1 & 8.4 & 1.4 & 9.2 & 3.9 & 8.4 & 5.1 & 82.2 \\
\hline Castilla y León & 7.8 & 2.0 & 7.7 & 1.5 & 8.5 & 3.4 & 7.3 & 4.0 & 90.9 \\
\hline Catalufía & 9.2 & 3.3 & 8.7 & 1.4 & 10.2 & 4.5 & 6.5 & 3.7 & 124.6 \\
\hline Ceuta and Melilla & 9.1 & 4.2 & 8.2 & 0.8 & 8.6 & 3.5 & .. &.. & .. \\
\hline Extremadura & 8.5 & 3.9 & 8.1 & 1.4 & 9.5 & 4.0 & 9.1 & 5.4 & 69.8 \\
\hline Galicia & 8.2 & 2.4 & 8.0 & 1.4 & 8.9 & 3.7 & 8.5 & 3.2 & 77.7 \\
\hline Madrid & 9.1 & 3.1 & 8.2 & 1.5 & 9.6 & 4.5 & 5.8 & 4.1 & 124.0 \\
\hline Murcia & 8.1 & 3.9 & 9.5 & 1.9 & 8.8 & 3.9 & 7.7 & 2.7 & 88.8 \\
\hline Navarra & 8.4 & 4.5 & 9.6 & 1.6 & 10.0 & 4.2 & .. & .. & 120.9 \\
\hline Pais Vasco & 7.5 & 2.9 & 80 & 1.5 & 8.2 & 3.8 & .. & .. & 118.1 \\
\hline Rioja (la) & 8.5 & 3.4 & 8.7 & 1.9 & 9.1 & 3.7 & 7.2 & 2.0 & 114.4 \\
\hline Valencia & 8.2 & 3.2 & 8.1 & 1.9 & 9.5 & 3.9 & 7.6 & 1.6 & 98.9 \\
\hline National level & 8.6 & 3.0 & 8.4 & 1.4 & 9.3 & 3.5 & 6.8 & 3.2 & 100.0 \\
\hline
\end{tabular}

1/ For the period 1992-96.

Sources: Isabelle Joumard and Aristomene Varoudakis, 2000, "Options for Reforming the Spanish Tax System"; OECD, Economics Department Working Paper 249. 
Table 4. Spain: Per Capita Value Added by Region, 1985-98

(As percent of national average)

\begin{tabular}{lrrrr}
\hline & 1985 & 1990 & 1995 & 1998 \\
\hline & & & & \\
Andalucía & 75.3 & 74.5 & 74.8 & 75.3 \\
Aragón & 112.5 & 113.5 & 112.9 & 114.4 \\
Asturias & 104.5 & 96.3 & 95.2 & 91.4 \\
Baleares & 154.9 & 150.3 & 157.1 & 154.5 \\
Canarias & 103.8 & 103.7 & 107.4 & 106.5 \\
Cantabria & 104.5 & 98.0 & 97.3 & 97.1 \\
Castilla la Mancha & 81.2 & 84.9 & 83.6 & 83.4 \\
Castilla y León & 92.6 & 93.0 & 94.5 & 96.4 \\
Cataluña & 130.0 & 130.6 & 129.7 & 129.4 \\
Comunidad Valenciana & 107.2 & 108.1 & 104.9 & 103.9 \\
Extremadura & 66.4 & 71.6 & 74.2 & 76.6 \\
Galicia & 85.2 & 87.4 & 88.7 & 88.8 \\
Madrid & 136.2 & 135.5 & 135.1 & 134.5 \\
Murcia & 86.8 & 87.0 & 85.0 & 82.8 \\
Navarra & 122.4 & 122.8 & 122.9 & 123.6 \\
Pais Vasco & 120.4 & 117.8 & 119.2 & 120.9 \\
Rioja (la) & 119.3 & 116.5 & 118.3 & 119.0 \\
Ceuta & 81.7 & 79.4 & 84.4 & 80.2 \\
Melilla & 83.6 & 76.1 & 77.3 & 74.4 \\
Total & 100.0 & 100.0 & 100.0 & 100.0 \\
& & & & \\
Memorandum items: & & & & \\
Standard deviation & 23.2 & 22.4 & 22.8 & 23.0 \\
Ratio, five richest to five poorest $1 /$ & 1.68 & 1.66 & 1.65 & 1.65 \\
& & & & \\
\hline & & & &
\end{tabular}

Sources: Instituto Nacional de Estadísticas; and Fund staff calculations.

1/ Ratio of per capita value added in the five richest regions to that of the five poorest regions. 
Table 5. Spain: Per Worker Value Added by Region, 1985-98 (As percent of national average)

\begin{tabular}{|c|c|c|c|c|}
\hline & 1985 & 1990 & 1995 & 1998 \\
\hline Andalucía & 88.3 & 88.8 & 89.1 & 87.8 \\
\hline Aragón & 100.0 & 101.7 & 94.6 & 96.2 \\
\hline Asturias & 100.0 & 97.3 & 99.7 & 98.5 \\
\hline Baleares & $\llbracket 18.1$ & 117.9 & 125.0 & 127.1 \\
\hline Canarias & 107.2 & 103.1 & 104.2 & 100.6 \\
\hline Cantabria & 95.3 & 94.8 & 98.4 & 99.1 \\
\hline Castilla la Mancha & 78.6 & 84.6 & 84.8 & 85.2 \\
\hline Castilla y León & 85.6 & 88.8 & 88.9 & 91.1 \\
\hline Cataluña & 116.5 & 111.7 & 111.8 & 111.9 \\
\hline Comunidad Valenciana & 98.4 & 97.8 & 100.1 & 100.1 \\
\hline Extremadura & 71.9 & 79.1 & 78.1 & 80.3 \\
\hline Galicia & 66.0 & 72.9 & 78.3 & 80.6 \\
\hline Madrid & 125.0 & 119.9 & 115.8 & 115.2 \\
\hline Murcia & 89.3 & 92.3 & 83.1 & 80.7 \\
\hline Navarra & 108.7 & 107.3 & 105.3 & 106.8 \\
\hline País Vasco & $\$ 19.5$ & 114.8 & 114.0 & 113.1 \\
\hline Rioja (la) & 102.1 & 100.5 & 96.6 & 95.9 \\
\hline Ceuta & 91.9 & 89.6 & 83.4 & 82.5 \\
\hline Melilla & 88.5 & 82.6 & 73.5 & 70.7 \\
\hline Total & 100.0 & 100.0 & 100.0 & 100.0 \\
\hline \multicolumn{5}{|l|}{ Memorandum items: } \\
\hline Standard deviation & 16.1 & 13.2 & 14.3 & 14.5 \\
\hline Ratio, five richest to five poorest $1 /$ & 1.49 & 1.37 & 1.33 & 1.32 \\
\hline
\end{tabular}

Sources: Instituto Nacional de Estadisticas; and Fund staff calculations.

1/ Ratio of per worker value added in the five richest regions to that of the five poorest regions. 


\section{Long Run Pension SImulations ${ }^{1}$}

\section{Demographics}

1. Projections are based on the National Statistical Institute (INE) basic scenario (current immigration and fertility trends). Further, it is assumed that the population of 16-64 year olds is uniformly distributed. Under these assumptions, the dependency ratio increases from 49 percent in 2005 to 89 percent in 2050. The demographic projections do not change across scenarios.

2. Our baseline simulation uses the same demographic assumptions as other studies on social security (Jimeno, 2000; Garcia, 2000; Herce and Meseguer, 2000). These assumptions derive from projections from INE and are highly sensitive to the standard demographic variables such as birth rate and life expectancy. Even more relevant is the role of migration. Spain is becoming a country with strong immigration and these flows, which are inherently very difficult to predict, could change the demographic variables in a dramatic way.

\section{Social security finances}

3. Social security contributions are assumed to increase with labor income, which in turn follows the changes in employment, labor productivity, and the GDP deflator. Employment growth may be affected by structural measures such as labor market reforms. Nevertheless, over the long-run (with the current elasticities) demographics prevail, and the labor force is projected to decline in the end of the projection period to about 11.5 million in the absence of reforms. Surpluses and deficits of the social security system are allowed to accrue in a reserve fund, which earns or pays interest on its balance.

4. Social security spending depends on the average pension and the number of retirees. The average pension is calculated as a weighted average of the old pensions, which increase with inflation but only partially with the productivity rate, and the new pensions, which are fully indexed to current wages. Every year 5.5 percent of the old retirees are replaced with new retirees. The total number of retirees is driven by demographics and the retirement age. In our benchmark the retirement age does not change so that the total number of retirees in 2030 is roughly equal to other studies that make the same assumptions (García, 2000).

5. Unemployment is supposed to decline gradually from 14.4 percent in 2000 to 4 percent in 2006 and stays constant afterwards. Finally, in order to focus just on pension expenditure dynamics we exclude unemployment benefits from social security.

\footnotetext{
${ }^{1}$ Prepared by Mario Mesquita (EU1) and Antonio Spilimbergo (RES).
} 


\section{Macroeconomic scenario}

6. GDP is assumed to grow in line with employment and productivity. While employment changes across scenarios, productivity is constant across scenarios. Average labor productivity increases 2 percent between 2000 and 2005 ; afterwards it stays at a constant increase of 1.5 percent.

7. Assuming an increase of one percent in the productivity rate would lower the projected social security deficit by about 8 percent of GDP at the end of the period. Only a 7 percent increase in productivity would assure the solvency of the social security in the next fifty years in absence of reforms. While it is impossible to know how productivity will grow in the next 50 years, this exercise suggests that it is highly implausible that productivity growth by itself can take care of the solvency problem.

8. The participation rate for the effective working age population is supposed to stay at 63.7 percent as it was in 1999. In a separate scenario we study the impact of a labor market reform that increases the participation rate to the average European level.

9. Real interest rates are supposed to be constant at three percent. This hypothesis is consistent with the idea that social security funds are invested in safe assets such as public bonds but may not be accurate if part of the fund is invested in equities. In this case the returns would be higher and the solvency problem can be postponed. Inflation averages 2 percent until 2010 and 1.7 afterwards.

10. The nonsocial security budget is assumed to be balanced after 2001 till the end of the period. Nonsocial security primary expenditure holds constant in terms of GDP at its 2001 level while nonsocial security revenues are allowed to diminish as the interest expenditure for nonsocial security public debt declines.

11. The assumptions about social security financing and the macro variables change slightly across studies. Our benchmark is quite similar to pessimistic scenarios of García (2000) and Jimeno (2000).

\section{Alternative scenario: reduction in early retirement}

12. In the first alternative scenario, the effective retirement age increases progressively so that in the year 2006 just 10 percent of the population between 55 and 64 is retired, compared to a current estimate of about 19 percent. The phasing out of early retirement results in a moderate improvement in the finances of the pension system, both by increasing the number of workers (and thus GDP) and by reducing the number of pensioners. 


\section{Alternative scenario: labor market reform}

13. The second alternative scenario assumes that in addition to the phasing out of early retirement, the authorities implement labor market reforms that are sufficient, over time, to raise the participation ratio for individuals aged 25-54 from its present level of about 63 percent to the EU average of 74 percent. This reform results in an improvement in the finances of the pension system primarily by increasing output. Further reforms that raised participation levels to those prevailing in the United States ( 81 percent) would have an even more positive impact on pension finances. 


\section{REFERENCES}

García, Miguel Angel, 2000, "El sistema de seguridad Social español en el año 2000" Confederacion sindical de comisiones obreras. Madrid

Herce, José A. and Javier Alonso Meseguer, 2000, "La reforma de las pensiones ante la revisión del Pacto de Toledo" Colección estudios económicos.

INE, 1999, "Escenarios futuros para la población de España. Período 1990-2050." INE Working Paper. Madrid.

Jimeno, Juan F., 2000, "El sistema de pensiones contributivas en España: cuestiones básicas y perspectivas en el medio plazo" Working Paper 2000-15. Fedea. Madrid. 


\section{Medium-Term Expenditure Management ${ }^{1}$}

1. In recent years a number of countries have moved to adopt formalized medium-term expenditure frameworks. Among EU members, for example, Finland, the Netherlands and the United Kingdom have fully-fledged frameworks in place (see Table 1). The objectives of the authorities have been several. One has been to underpin medium-term fiscal goals linked to broader macroeconomic objectives, including for euro-area candidates those of the Maastricht criteria on the road to monetary union. Another goal-prominent in the case of the United Kingdom for example - has been to ensure that spending restraint is achieved on a strategic basis, so that capital expenditure does not unduly suffer-or ceases to suffer--the burden of adjustment. In Finland and the Netherlands, a further key goal was to ensure the room to pursue in tandem both fiscal consolidation and a reduction in tax burdens. In all these cases, moreover, medium-term fiscal strategies have served to catalyze consensus in the cabinet of ministers on overall expenditure priorities, thereby minimizing the risk of a yearby-year reopening of debates on priorities. In this respect, most importantly, it has also provided the managers of government departments and agencies with a clear planning horizon, favoring structural reforms and strategic shifts of resources as against year-by-year freezes and ad hoc cuts.

2. As experience has been gained with these frameworks, a number of pointers have emerged to successful design features, although areas remain in which it is easier to identify tensions than the ideal solutions. Among the points on which recent experience is quite suggestive, the following stand out:

- A period extending to cover two to three years after the initial annual budget year provides a realistic time horizon.

- While it is both useful and appropriately transparent to provide government expenditure plans to the parliament and the public, it is not necessarily prudent to seek to vote expenditure authorizations for the entire period: typically parliamentary authorizationother than for certain entitlements-covers the traditional budget year.

- Some countries have adopted very conservative macroeconomic assumptions for their expenditure frameworks, but over time experience with this has pointed to dangers. In effect, policy-makers build in over performance to their expectations, and the rigor of the system is diminished.

- Particularly where more rapid than projected economic growth has resulted in revenue overperformance, there has been a risk of imparting a pro-cyclical bias to policy: rather than let stabilizers operate, the fruits of cyclical revenue increases have tended to be

\footnotetext{
${ }^{1}$ This appendix is distilled from previous research by C.M. Watson (EU1), Craig Beaumont (PDR) and Christina Daseking (EU1).
} 
divided among tax cuts, higher expenditure, and some additional deficit reduction. Understandings are needed at the outset of the framework period to safeguard the operation of revenue stabilizers over the cycle.

- Generally, the coverage of ceilings has been de facto fairly comprehensive, extending to transfers to local authorities and to at least some social security spending; and judging by a wider range of countries, where government is relatively decentralized, commitments related specifically to expenditure can also be underpinned more broadly by an internal stability pact on overall fiscal deficit goals among the different levels of government.

- To provide some incentive, overperformance by agencies or departments has generally been rewarded by allowing a certain amount of carry-over between budget years.

3. While there is some convergence in experience on the above points, there are a number of more difficult issues, where countries have tried different solutions but it is hard to point to clear lessons:

- There is a difficult question whether to develop out-year projections in current or in constant prices. Where is expenditure has been credibly reduced to very low levels, making projections in real terms certainly facilitates a transparent review of resource priorities. On the other hand, when wages move off track, or relative price shocks occur, the development of rules to deal ex ante with the problem is difficult, and some in-built laxity may arise: higher than projected cost increases may be accommodated, and managers may asymmetrically spend more in cases where relative prices declines create room under ceilings. For this reason the United Kingdom has developed a nominal medium-term framework, but significant experience has yet to be gained with this.

- The design of a system that allows expenditure stabilizers to operate is particularly difficult. In Finland and the Netherlands, for example, cyclically varying social transferssuch as the unemployment benefit-are captured under ceilings, meaning that there is an incentive to offset cyclically higher transfers by other expenditure cuts. For this reason the UK approach is to exclude various entitlement programs from the expenditure ceilings, subjecting them to separate review and authorization--but not all commentators would consider this division of expenditure helpful in other respects. A further potential problem relating to stabilizers arises in decentralized systems, whether under one-year or mediumterm expenditure approaches: lower levels of government tend de facto or de jure to pursue balanced budget strategies: thus, over the medium term, they will tend to neutralize the operation of expenditure stabilizers.

- There is, finally, a dilemma how to deal in practice with slippages - particularly in areas where an immediate claw back may be difficult-such as wage costs or healthcare costs. In some cases, a contingency is included in each year's framework, to allow for some shocks, but this may inject an element of moral hazard into the process. 
Table 1. Medium-Term Public Expenditure Programming in Finland, the Netherlands, and the United Kingdom

\begin{tabular}{|c|c|c|c|c|}
\hline & Finland & Nethedlands & United Kingdon & Pros and Cons \\
\hline Horizon & $\begin{array}{l}\text { Four years, on annually } \\
\text { rolling basis }\end{array}$ & $\begin{array}{l}\text { Four years, set at outset of } \\
\text { coalition period }\end{array}$ & $\begin{array}{l}\text { Three years on a two-year } \\
\text { rolling basis (i.e., with } \\
\text { successive frameworks } \\
\text { overlapping by one year) for } \\
\text { non-cyclical expenditures } \\
\text { (see coverage); cyclical or } \\
\text { volatile spending is } \\
\text { managed on an annual basis }\end{array}$ & $\begin{array}{l}\text { Longer horizon and fixed ceilings provide more } \\
\text { certainty and discipline to managers, but reduce } \\
\text { flexibility in case of changing circumstances }\end{array}$ \\
\hline Objective & $\begin{array}{l}\text { In past, mainly geared to } \\
\text { deficit reduction; in future } \\
\text { also to provide room for } \\
\text { tax cuts }\end{array}$ & $\begin{array}{l}\text { To achieve a parallel } \\
\text { reduction in the deficit and } \\
\text { tax burden }\end{array}$ & $\begin{array}{l}\text { Over the cycle, to balance } \\
\text { the current budget and } \\
\text { maintain investment (and } \\
\text { hence borrowing) at a } \\
\text { sustainable level, while } \\
\text { meeting the Government's } \\
\text { priorities }\end{array}$ & $\begin{array}{l}\text { Prominence of deffcit goal should reflect } \\
\text { considerations of public debt sustainability } \\
\text { (factoring in demographics), plus room for } \\
\text { stabilizers; goal for taxes should reflect, inter alia, } \\
\text { extent tax wedge distorts labor market and thus } \\
\text { long-run fiscal outlook }\end{array}$ \\
\hline $\begin{array}{l}\text { Coverage of } \\
\text { medium-term } \\
\text { spending targets }\end{array}$ & $\begin{array}{l}\text { Total central government } \\
\text { expenditures and } \\
\text { subceilings for individual } \\
\text { ministries, including } \\
\text { transfers to local } \\
\text { governments and social } \\
\text { security funds; excludes } \\
\text { local governments' self- } \\
\text { financed expenditure }\end{array}$ & $\begin{array}{l}\text { Expenditures of central } \\
\text { government (excluding } \\
\text { infrastructure fund) and } \\
\text { social security funds; } \\
\text { subceilings on central } \\
\text { government, health, and } \\
\text { social security }\end{array}$ & $\begin{array}{l}\text { Departmental Expenditure } \\
\text { Limits (DELs), covering } \\
\text { most non-cyclical primary } \\
\text { expenditures (some half of } \\
\text { total expenditures); includes } \\
\text { central government support } \\
\text { for local government but not } \\
\text { local authoritity's self- } \\
\text { financed expenditure }\end{array}$ & $\begin{array}{l}\text { Comprehensive coverage is more transparent and } \\
\text { effective but may constrain automatic stabilizers } \\
\text { unduly; inclusion of local governments requires } \\
\text { their autonomy to be limited, with risks of } \\
\text { adverse incentive/accountability effects }\end{array}$ \\
\hline $\begin{array}{l}\text { Statutory nature } \\
\text { of medium-term } \\
\text { spending targets }\end{array}$ & $\begin{array}{l}\text { Budget year binding; outer } \\
\text { years agreed by cabinet as } \\
\text { nonbinding norm to } \\
\text { ministries; published but } \\
\text { not submitted to parliament }\end{array}$ & $\begin{array}{l}\text { Budget year binding; outer } \\
\text { years politically but not } \\
\text { legally binding; submitted } \\
\text { to parliament for } \\
\text { information; contingency } \\
\text { reserve to deal with } \\
\text { changing circumstances }\end{array}$ & $\begin{array}{l}\text { Budget year binding; outer } \\
\text { years not legally binding but } \\
\text { overall DELs announced in } \\
\text { parliament; contingency } \\
\text { reserve to deal with } \\
\text { changing circumstances }\end{array}$ & $\begin{array}{l}\text { Politically binding targets favor discipline and } \\
\text { credibility; legally binding limits might constrain } \\
\text { flexibility unduly }\end{array}$ \\
\hline
\end{tabular}




\begin{tabular}{|c|c|c|c|c|}
\hline & Finland & Nethorlands & United Kingdom & Pros and Cons \\
\hline $\begin{array}{l}\text { Nominal or real } \\
\text { targets }\end{array}$ & $\begin{array}{l}\text { Medium-term at constant } \\
\text { prices of budget year; for } \\
\text { new budget translated to } \\
\text { current prices based on } \\
\text { specific price and cost } \\
\text { deflators }\end{array}$ & $\begin{array}{l}\text { Medium-term at constant } \\
\text { prices; for one-year } \\
\text { budget, translated to } \\
\text { current prices based on } \\
\text { projected GDP deflator }\end{array}$ & $\begin{array}{l}\text { All targets set in current } \\
\text { prices }\end{array}$ & $\begin{array}{l}\text { Medium-term based on constant prices facilitates } \\
\text { real resource planning; one-year budget must be } \\
\text { nominal as inflation anchor; use of category- } \\
\text { specific deflators may risk discouraging desired } \\
\text { adjustment to relative price changes }\end{array}$ \\
\hline $\begin{array}{l}\text { Macroeconomic } \\
\text { assumptions }\end{array}$ & $\begin{array}{l}\text { Underlying assumptions } \\
\text { reflect central forecast }\end{array}$ & $\begin{array}{l}\text { Growth forecast cautious; } \\
\text { rule splits "growth } \\
\text { dividend" between } \\
\text { additional deficit and tax } \\
\text { cuts }\end{array}$ & $\begin{array}{l}\text { Growth forecast at } \\
\text { conservative end of potential } \\
\text { output range }\end{array}$ & $\begin{array}{l}\text { Reasonably prudent assumptions on growth, } \\
\text { inflation, and interest rates essential; but, if } \\
\text { unduly so, may over time create credibility } \\
\text { problems and "second-guessing" }\end{array}$ \\
\hline $\begin{array}{l}\text { Adjustments in } \\
\text { target levels for } \\
\text { outer years }\end{array}$ & $\begin{array}{l}\text { Ceilings for outer years can } \\
\text { be adjusted; automatic } \\
\text { adjustment for wage and } \\
\text { salary increases }\end{array}$ & $\begin{array}{l}\text { No adjustment in real } \\
\text { expenditure; only } \\
\text { "automatic" translation of } \\
\text { targets into current prices } \\
\text { based on aggregate } \\
\text { inflation forecast }\end{array}$ & $\begin{array}{l}\text { Medium-term DELs in } \\
\text { current prices are adjusted } \\
\text { only if new inflation } \\
\text { forecasts differ significantly } \\
\text { from original projections }\end{array}$ & $\begin{array}{l}\text { Adjustments provide flexibility in case of } \\
\text { unanticipated exogenous developments or desired } \\
\text { policy changes but reduce imposed discipline, } \\
\text { transparency, and credibility of the system }\end{array}$ \\
\hline $\begin{array}{l}\text { Autonomy and } \\
\text { incentives at } \\
\text { lower levels }\end{array}$ & $\begin{array}{l}\text { Ministries and agencies } \\
\text { bound by annual budget; } \\
\text { some appropriations } \\
\text { transferable, avoiding } \\
\text { "forced" consumption at } \\
\text { end of fiscal year }\end{array}$ & $\begin{array}{l}\text { Ministries and agencies } \\
\text { bound by annual budget; } \\
\text { part of funds can be } \\
\text { carried over to next year; } \\
\text { no penalties have been } \\
\text { imposed for repeated } \\
\text { healthcare overruns }\end{array}$ & $\begin{array}{l}\text { Individual departments } \\
\text { bound by DELs; within } \\
\text { these limits departments can } \\
\text { recycle any efficiency } \\
\text { savings they make; unspent } \\
\text { DEL funds can be carried } \\
\text { over to next year; overruns } \\
\text { are avoided by strict DELs }\end{array}$ & $\begin{array}{l}\text { Carry-over discourages excessive spending at end } \\
\text { of fiscal year; tolerance of overnus lowers } \\
\text { credibility but is diffictlt to avoid, if coverage } \\
\text { includes cyclical items or other expenditures, that } \\
\text { are difficult to control }\end{array}$ \\
\hline $\begin{array}{l}\text { Output } \\
\text { objectives and } \\
\text { quality control }\end{array}$ & $\begin{array}{l}\text { Agencies establish result } \\
\text { and efficiency targets, with } \\
\text { ex-post evaluation by } \\
\text { ministries }\end{array}$ & $\begin{array}{l}\text { No formalized output } \\
\text { objectives }\end{array}$ & $\begin{array}{l}\text { Publication of Public } \\
\text { Service Agreements } \\
\text { alongside spending plans, } \\
\text { stating departments' goals } \\
\text { and setting specific } \\
\text { quantified policy and } \\
\text { efficiency targets }\end{array}$ & $\begin{array}{l}\text { Experience with performance objectives positive; } \\
\text { but tensions between output objectives and } \\
\text { spending restraint possible, if output objectives } \\
\text { introduced before budgetary discipline is } \\
\text { inculcated }\end{array}$ \\
\hline
\end{tabular}




\section{Physical Capital AdJustment within SPain: LoNG- AND SHORT-RUN ANALYSES ${ }^{1}$}

1. Large differences in unemployment rates have persisted for a number of decades among the Spanish regions, and have been associated with macroeconomic costs--a higher NAIRU and lower potential output-and social distress. Differences in per capita incomes also remain large, having declined only gradually over the past few decades. In highly flexible markets, differences in both unemployment rates and per capita incomes might have been reduced rapidly through adjustment in both the labor market and the capital market. Previous studies have shown that large and persistent unemployment differences among the Spanish regions may be attributed in part to labor market rigidities, including a relatively centralized wage bargaining system (Mauro, Prasad, and Spilimbergo, 1999). ${ }^{2}$ The question why capital does not move to correct unemployment imbalances however has not been addressed in previous work; the role of capital movement in the convergence of per capita income incomes also deserves further consideration. This appendix seeks to fill these gaps, and to complement previous work on labor market adjustment, by focusing on capital market adjustment.

2. More generally and beyond the case of Spain, capital market adjustment remains a relatively unexplored area in economics-certainly by comparison with labor market adjustment. Most of the existing work on capital market adjustment has addressed the issue of why capital does not move to developing countries, where it is relatively scarce. Previous research on this issue, exemplified by a seminal article by Lucas (1990), has typically focused on long-run developments in relative per capita incomes and relative capital abundance. The present chapter applies this approach to the Spanish regions, drawing on exceptionally detailed data sets on income, labor, private capital, public capital, and human capital collected by the Instituto Valenciano de Investigaciones Económicas and Fundación Banco Bilbao Vizcaya. Short-run capital market adjustment to regional shocks has not been analyzed in previous work. The present chapter uses a vector autoregression methodology to estimate the response of physical capital to regional shocks: in this respect, it makes an original contribution to this line of research, with implications not only for Spain but for other countries as well.

\section{A. Long-Run Analysis}

3. This section analyzes long-run developments in private capital stocks for the 17 Spanish regions. It shows that developments in the regions' private capital stocks have

\footnotetext{
${ }^{1}$ Prepared by Paolo Mauro and Antonio Spilimbergo (both RES).

${ }^{2}$ Differences across regions in real wages and unit labor costs are too small and unrelated to unemployment differences to reinforce incentives for workers to migrate out of, and for firms to migrate toward, high unemployment regions.
} 
responded to differences in the rate of return on capital, resulting in gradual convergence of the regions' capital/labor ratios. At the same time, the rate of return on capital does not seem to be higher in high-unemployment regions and, consistent with this, no tendency has been observed for capital to move toward high-unemployment regions. Unemployment differences are thus not being corrected through this mechanism.

\section{Capital movement and per capita incomes across regions}

4. While previous studies (including Dolado et al., 1994, and García-Greciano et al., 1999) have shown that GDP per capita and GDP per employee have converged across the Spanish regions during the past few decades, these studies have not focused on the extent to which this is accounted for by convergence in the various factors of production. Using a detailed data set on private capital, public capital, and educational attainment, this chapter shows that private capital per employee has converged, albeit gradually, since 1970 (despite some divergence in 1986-92, a period characterized by large external shocks). In this respect, private capital has evolved in accordance with the law of diminishing returns, under which a factor will flow toward the regions where it is relatively scarce, that is, where its marginal product is higher. By contrast, human capital has not shown much tendency to converge, and public capital converged slowly and only until 1990. This is confirmed by developments in the coefficient of variation (standard deviation divided by the mean) across the 17 Spanish regions for GDP and the endowments of public capital and private capital, all as a ratio to employment, and human capital (defined, for simplicity, as the share of employment with a secondary or higher degree), in 1967-95 (Figure 1). The capital/labor ratio has therefore displayed convergence in dispersion (or $\sigma$-convergence).

5. Moreover, the capital/labor ratio has tended to rise more rapidly in regions that started off with a lower-than-average ratio, i.e., it has also displayed $\beta$-convergence. In a panel regression of the regional capital/labor ratio on its lag, human capital, public capital, yearly dummies to control for nationwide developments, and regional dummies, the estimated speed of convergence implies a half-life of 8.6 years for the difference in the capital/labor ratio between any two regions. ${ }^{3}$ In this sense, therefore, private capital has moved, albeit gradually and slowly, from capital-rich regions to capital-poor regions.

\section{Capital movement and regional unemployment}

6. By contrast, private capital has not moved from low-unemployment regions to highunemployment regions. This finding might reflect two possibilities: first, that the return on capital is unrelated to regional unemployment rates; second, that the magnitude of regional shocks and the relatively slow pace of capital adjustment are such that the regions are almost always in disequilibrium. Both possibilities seem plausible, and they might well coexist: they are considered in the next sections.

${ }^{3}$ The appendix provides details on the estimation. 
Figure 1. Spain: Coefficients of Variation, 1971-2000

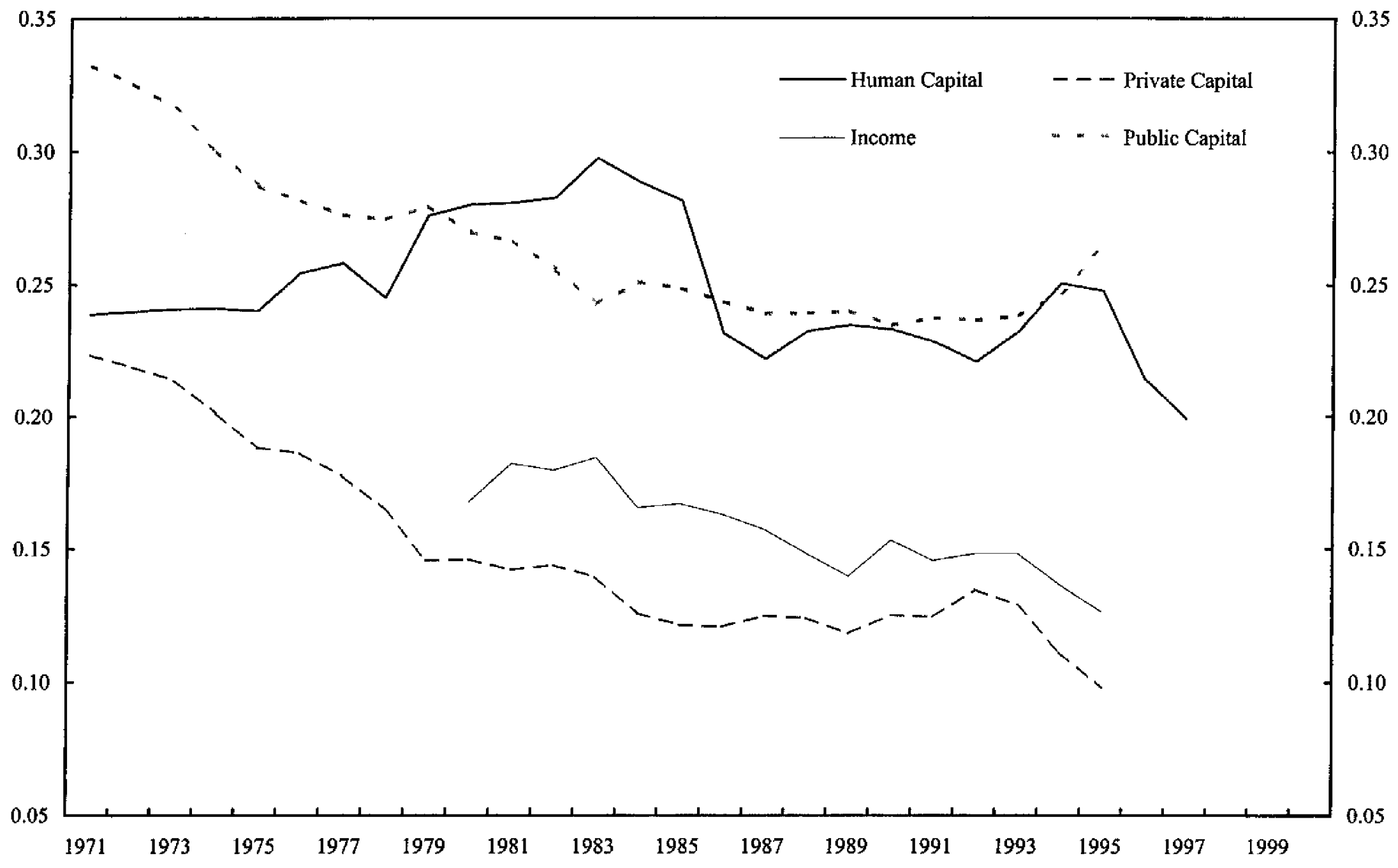

Source: Staff calculations. 
7. Private capital might have been expected to flow toward regions with relatively high unemployment, whether because of the availability of large numbers of unemployed workers, or because of lower wages possibly associated with high unemployment, assuming that the relative availability of other factors, such as human capital or public capital, did not offset this tendency.

8. To estimate the return to private capital in the various regions, and to assess the extent to which regional differences in the return to private capital are accounted for by differences in public capital and human capital, it is assumed that a region's production function takes a Cobb-Douglas form as follows:

$Y_{i}=A_{i} K_{i}^{\alpha} L_{i}^{\beta} P_{i}^{\gamma} H_{i}^{\delta}$

Where $Y$ is output, $K$ is private capital, $L$ is labor (the number of workers, regardless of education), $P$ is public capital, $H$ is human capital, $A$ is total factor productivity (a residual), and the subscript $i$ denotes region $i$. The return to private capital is the marginal product of capital:

$R_{i}=\partial Y_{i} / \partial K_{i}=A_{i} \alpha K_{i}^{\alpha I} L_{i}^{\beta} P_{i}^{\gamma} H_{i}^{\delta}$

Taking logarithms, rearranging, and taking differences with respect to the national average (the latter denoted by subscript $E$ ), the difference in region $i$ 's return to private capital with respect to the national average consists of the following components:

$$
\begin{aligned}
& \ln \left(R_{i}\right)-\ln \left(R_{E}\right)=(\alpha-1)\left[\ln \left(K_{i} / L_{i}\right)-\ln \left(K_{E} / L_{E}\right)\right]+\gamma\left[\ln \left(P_{i} / L_{i}\right)-\ln \left(P_{E} / L_{E}\right)\right]+ \\
& +\delta\left[\ln \left(H_{i} / L_{i}\right)-\ln \left(H_{E} / L_{E}\right)\right]+\left[\ln \left(A_{i}\right)-\ln \left(A_{E}\right)\right]-(1-\alpha-\beta-\gamma-\delta)\left[\ln \left(L_{i}\right)-\left[\ln \left(L_{E}\right)\right]\right.
\end{aligned}
$$

9. Figure 2 shows the various components of the difference between the marginal return to private capital in the 17 Spanish regions and the national average in 1990, assuming that $\alpha=\beta=\gamma=0.3$ and $\delta=0.1{ }^{4}$ For example, the relatively low marginal return on private capital in Galicia is largely accounted for by Galicia's relatively high stock of private capital per worker.

10. The key message from Figure 2 is that the extent to which differences in public capital and human capital account for differences in returns on private capital among the Spanish regions is rather limited; differences in private capital stocks per worker play a much greater role in this respect.

11. Nevertheless, differences in the estimated return to private capital across the regions are large, and they might provide incentives for private capital to move toward regions with

${ }^{4}$ The results do not change much using alternative parameter values within a plausible range. 
Figure 2. Spain: Decomposition of Rate of Return, 1990
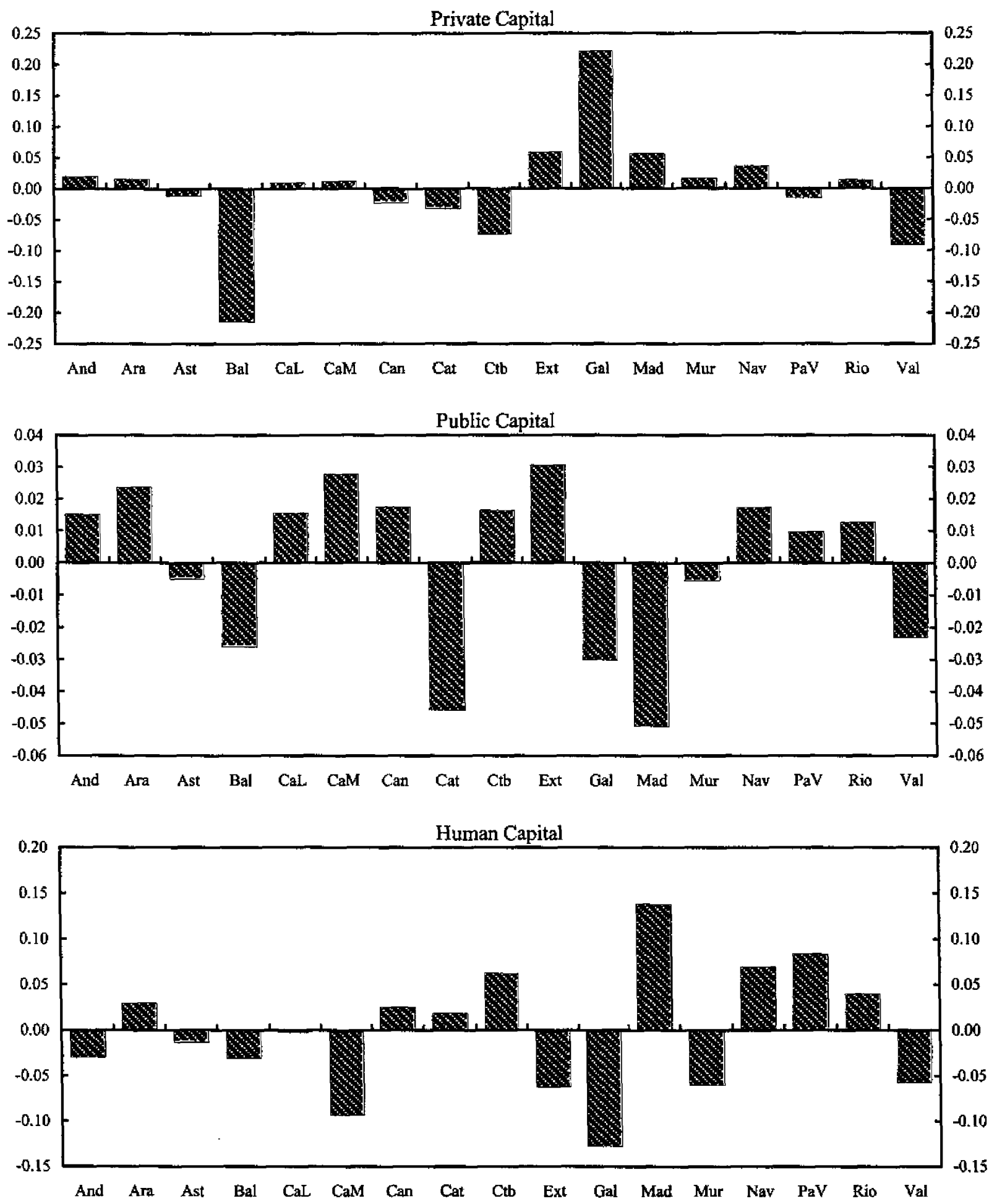

Source: Staff calculations. 
higher relative returns. However, the estimated return to private capital is not significantly associated with regional unemployment. Figure 3 shows the correlation between the unemployment rate and the estimated total return on capital (constructed from the formula above assuming that $A_{i}$ is the same for all regions) in 1990. The main message is that there is no apparent correlation between the rates of returns and local unemployment rates. Therefore, despite the persistence of large regional differences in unemployment rates, no significant evidence of failures in the capital market is found using this approach.

12. Regression analysis on a panel of the Spanish regions in 1966-95 does not yield significant evidence of any positive link between unemployment and investment, either (Table 1). The left-hand-side variable is the investment rate per worker, and the right-handside variables are lags of the unemployment rate, the investment rate per worker, the private capital/labor ratio, the public capital/labor ratio, and the human capital index. The regression includes yearly dummies, to control for nationwide developments, and regional dummies, to ensure that the coefficients are not biased by omitted factors that might be correlated across regions with the right-hand-side variables. The coefficient on lagged regional unemployment is negative and significant. A higher capital/labor ratio is found to be associated with lower investment, as expected in the presence of diminishing returns to capital. The coefficient on the lagged investment rate is found to be large and significant, suggesting that adjustment costs in investment are considerable.

Table 1. Dependent Variable $\mathbf{I}_{\mathfrak{t}}$

\begin{tabular}{lrrr}
\hline & Coefficient & Standard Error & \multicolumn{1}{c}{$\mathrm{t}$} \\
\hline $\mathrm{I}_{\mathrm{t}-1}$ & 0.281 & 0.044 & 6.337 \\
$\ln (\mathrm{K} / \mathrm{L})_{\mathrm{t}-1}$ & -0.056 & 0.012 & -4.882 \\
$\ln (\mathrm{P} / \mathrm{L})_{\mathrm{t}-1}$ & -0.012 & 0.010 & -1.105 \\
$\ln (\mathrm{H})_{\mathrm{t}-1}$ & -0.002 & 0.014 & -0.147 \\
$\mathrm{U}_{\mathrm{t}-1}$ & -0.106 & 0.048 & -2.223
\end{tabular}

$\mathrm{R}^{2}=0.5650$

Note: There are 510 observations. The list of right-hand-side variables also includes 17 regional dummies and 29 yearly dummies, whose coefficients are not reported for the sake of brevity.

13. These results suggest that even though private capital gradually responds to differences in returns across regions, returns are not higher in higher-unemployment regions; accordingly, there is no tendency for capital to move toward regions with relatively high unemployment. 
Figure 3. Spain: Correlation between Unemployment and Return on Private $\mathrm{K}$

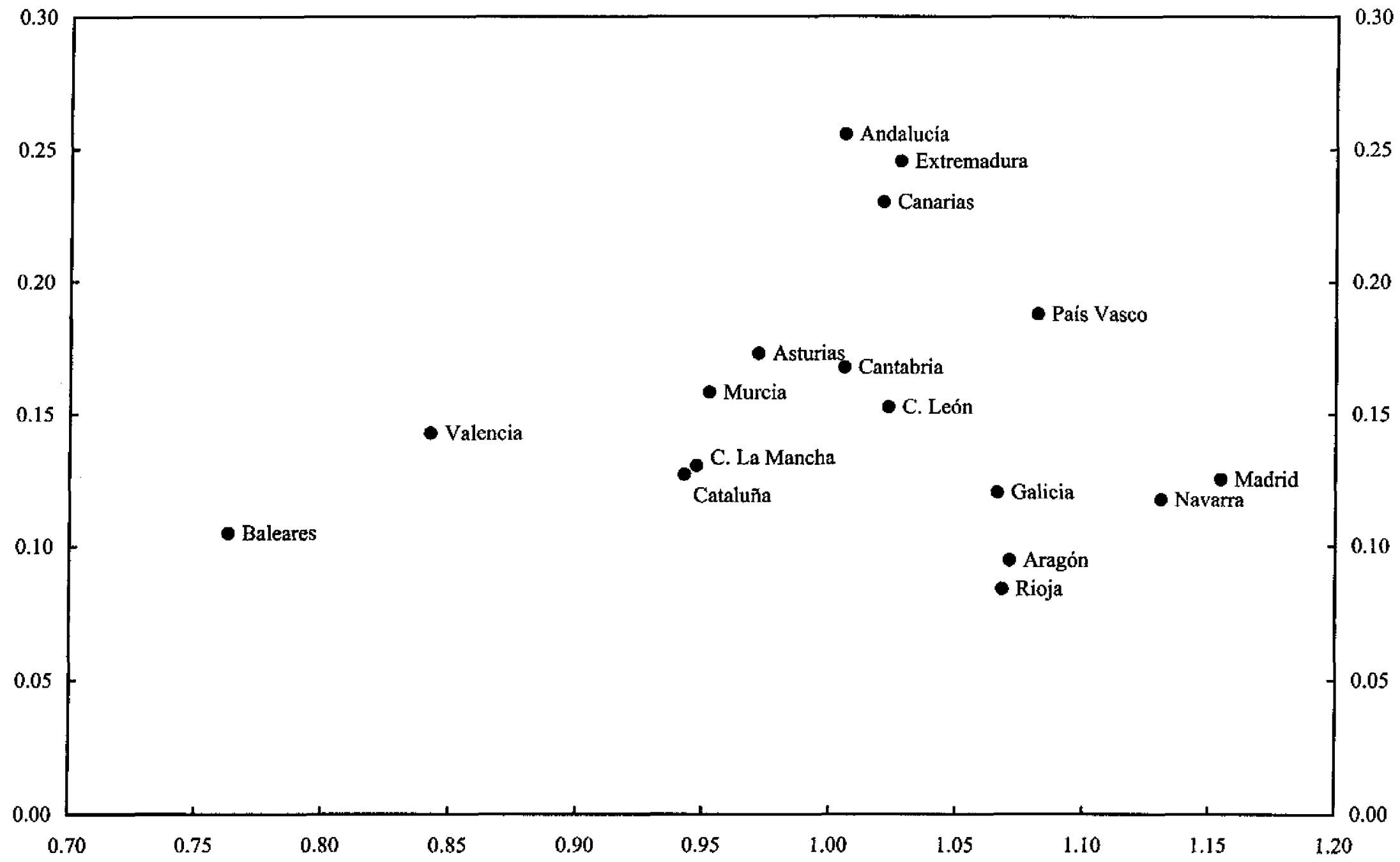

Source: Staff calculations. 


\section{B. Short-Run Analysis}

14. This section analyzes the response of a region's capital, labor, and output to a regional shock. Specifically, it asks the following questions: when a region is hit by a shock that results in lower output growth, to what extent does the adjustment take place through a slowdown in labor input, capital input, and total factor productivity? How rapidly do capital and labor adjust? Does the immediate impact of the shock differ from its long-run effect?

15. In order to answer these questions, a vector autoregression system is estimated for a panel consisting of the 17 Spanish region over 1983-95, with equations for (i) capital accumulation, (ii) employment growth, and (iii) GDP growth. Before moving to the estimation, two preliminary issues need to be addressed. First, how are national shocks reflected in regional variables, and what is the most appropriate way to control for national shocks? Second, as changes in output growth and input growth are jointly determined, how can exogenous shocks to the regions be identified?

\section{Regional response to national shocks}

16. Regional economies are subject to both national shocks, such as changes in monetary policy or oil prices, and regional shocks, such as a bad weather in the region. Moreover, the various regions may respond differently to national shocks: for example, the effects of an oil price shock may be expected to be smaller in agricultural regions than in industrial regions. In order to assess whether the response of employment, private capital, and output to national shocks is similar across regions, the following regression is estimated for each region:

$\Delta \mathrm{X}_{\mathrm{it}}=\alpha_{\mathrm{i}}+\beta_{\mathrm{i}} \Delta \mathrm{X}_{\mathrm{t}}+e_{\mathrm{it}}$, where $\mathrm{X}$ can be employment, private capital, or output, $\Delta \mathrm{X}_{\mathrm{it}}$ is the regional growth rate, and $\Delta X_{t}$ is the national growth rate. There is considerable variation in the estimated $\beta_{i}$ coefficients: when national employment grows by 1 percentage point above its trend, extra regional employment growth above regional trends ranges from 1.2 percentage points in Catalonia to 0.5 percentage point in Cantabria or Galicia. Similar variation is evident in the response of regional investment or output to national developments.

17. The appropriate way to control for national shocks in the VAR system estimation is therefore by using yearly dummies, because this allows the regional responses to national shocks to differ across regions. ${ }^{5}$ By contrast, the much-used Blanchard-Katz (1992) method, which consists of using regional differences with respect to the national average when estimating the VAR system, would not be appropriate in this case because it assumes that the responses of regional employment to the national business cycles are the same for all regions.

\footnotetext{
${ }^{5}$ Given the large sample, using yearly dummies is not very costly in terms of reduced degrees of freedom.
} 
18. Besides providing information on the appropriate way to control for national business cycles, the previous analysis gives information on the relative importance of regional and national shocks for employment, the capital stock, and income. Innovations in regional employment can be explained by national developments in employment to a lesser extent than developments in regional capital stocks can be explained by national developments in the capital stock; national developments play an even smaller role in the case of income. The average $\mathrm{R}^{2}$ is 0.55 in the employment regressions, 0.73 in the private capital growth regressions, and 0.40 in the income growth regressions. ${ }^{6}$

\section{Identification and shocks}

19. To identify exogenous shocks to the regions, this chapter considers external shocks, such as changes in the price of oil, and makes use of the fact that their impact on the various regions will differ in a predictable manner. ${ }^{7}$ The exogenous shock is defined as:

Shock $_{i t}=(\text { price of oil in real terms })_{t}$ share of workers in manufacturing ${ }_{i}$

20. When the real price of oil increases, all regions will be adversely affected, but some regions - presumably those with a greater share of industry in regional output - will be affected more strongly than others will. ${ }^{8}$ This section considers how these shocks affect regional capital, labor, and output, controlling for developments in the Spanish economy as a whole. In other words, the impulse responses trace the extent to which capital, labor, and output grow more slowly than would be expected on the basis of developments in these variables at the national level.

\footnotetext{
${ }^{6}$ By comparison, the $\mathrm{R}^{2}$ on analogous regressions for employment growth is 0.66 in the 50 U.S. states (Blanchard and Katz, 1992) and 0.20 in the European regions (Decressin and Fatás, 1995). A factor that may contribute to a lower $\mathrm{R}^{2}$ in Spain than in the United States may be that agriculture - a sector that is especially prone to regional shocks-plays a larger role in Spain than in the United States.

${ }^{7}$ Identification is attained only thanks to the fact that these external, nationwide shocks interact with region-specific variables so as to affect the various regions differently but in a predictable manner. Neither nationwide shocks nor region-specific variables would be sufficient to give identification in the absence of these interactions.

${ }^{8}$ This strategy to identify exogenous shocks is similar to that adopted by Davis et al. (1995).
} 


\section{VAR estimation}

21. The following system is estimated:

$$
\begin{aligned}
& \Delta Y_{i t}=\alpha_{i l}+\beta_{l}(L) \Delta Y_{i t-1}+\gamma_{l}(L) \Delta L_{i t-1}+\delta_{l}(L) \Delta K_{i t-1}+\text { regional dummies }+ \text { yearly } \\
& \text { dummies }+ \text { shock }_{i t-I}+\varepsilon_{i y t} \\
& \Delta L_{i t}=\alpha_{i 2}+\beta_{2}(L) \Delta Y_{i t-1}+\gamma_{2}(L) \Delta L_{i t-1}+\delta_{2}(L) \Delta K_{i t-1}+\text { regional dummies }+ \text { yearly } \\
& \text { dummies }+ \text { shock }_{\text {it- } 1}+\varepsilon_{\text {itt }} \\
& \Delta K_{i t}=\alpha_{i 3}+\beta_{3}(L) \Delta Y_{i t-1}+\gamma_{3}(L) \Delta L_{i t-1}+\delta_{3}(L) \Delta K_{i t-1}+\text { regional dummies }+ \text { yearly } \\
& \text { dummies }+ \text { shock }_{i t-1}+\varepsilon_{i k t}
\end{aligned}
$$

Where $Y_{i t} L_{i t}, K_{i t}$ are regional income, employment, and capital. Two lags of each variable are included to allow for feedback effects. Annual dummies are included to control for nationwide developments, as explained above. Region-specific trends are included, in light of the evidence on long-run convergence presented above. ${ }^{9}$ The sample includes the 17 Spanish provinces and covers the period 1980-1995, yielding 221 observations (allowing for lags).

22. The results are robust when the same system is estimated using a different shock, defined as a region's openness in 1998 times Spain's terms of trade index. The results are also similar when the system is estimated controlling for human capital and public capital; the baseline specification reported above is more parsimonious in terms of degrees of freedom.

23. Impulse response functions (Figure 4) trace the response of output, capital, and labor to a one standard deviation shock to the price of oil interacted with industry output as a share

\footnotetext{
${ }^{9}$ In their seminal paper that first used this type of approach to analyze regional labor market developments, Blanchard and Katz (1992) considered all variables as differences with respect to the national average. By using regional variables while controlling for year-specific dummies to capture nationwide developments, the approach used in the present chapter constitutes a simple generalization of the Blanchard and Katz (1992) approach.

Straightforward restrictions on the parameters would yield the Blanchard and Katz (1992) approach as a special case, but the restrictions would be rejected by formal specification tests.
} 
Figure 4. Spain: Impulse Responses

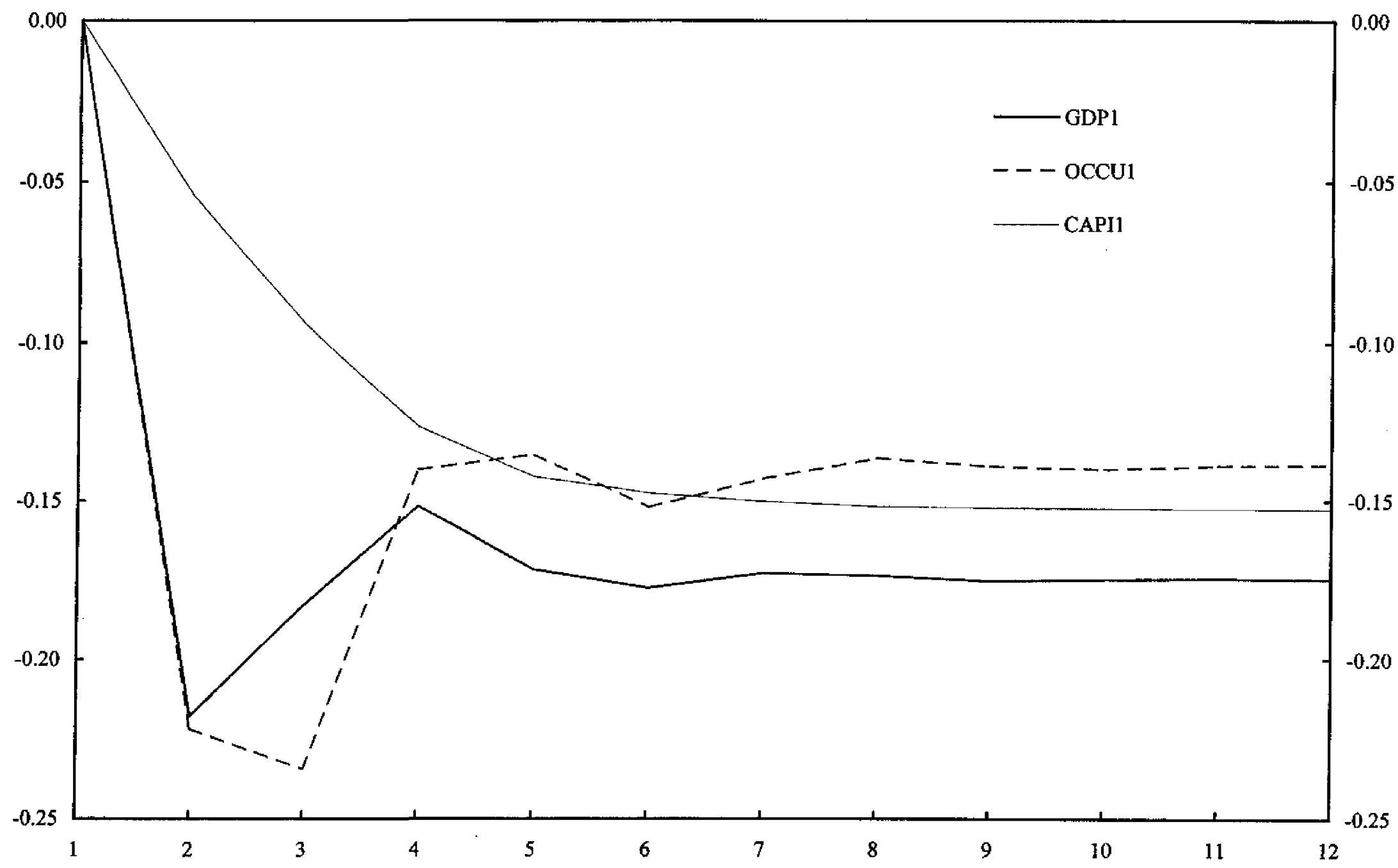


of total regional output. ${ }^{10}$ These responses are estimated fairly precisely, as seen from the relatively narrow one standard deviation confidence intervals (Figure 5). The estimated impact on output is a 0.33 percentage point drop taking place entirely in the first year after the shock; output recovers somewhat in the following years, stabilizing at 0.26 percentage point below its preshock level in the long run. The most interesting result is the difference in the dynamic adjustment of capital and labor. The impact on employment is initially relatively strong ( -0.25 percentage point in the first year), but employment recovers in the following years to 0.16 percentage point below its preshock level in the long run. ${ }^{11}$ By contrast, the impact on capital is gradual: it amounts only to -0.06 percentage point in the first year but becomes stronger over time; it is fully felt after 4 years, when it stabilizes at -0.17 percentage point below its preshock level. After 4 years and in the long run, the proportional decline in capital and labor is the same, that is, the capital/labor ratio is back to its preshock level.

24. The impulse response functions suggest that the immediate brunt of adjustment falls upon labor, rather than capital, with the capital/labor ratio returning to its preshock level only gradually. This different speed of adjustment is more likely to reflect technical difficulties in altering the capital stock rather than rigidities in the market for physical capital. This interpretation is consistent with the view that private physical capital is highly firm-specific and can be moved only at a significant cost (Ramey and Shapiro, 2000). Nevertheless, a more firm interpretation of this result cannot be provided in the absence of comparable studies for other countries.

25. The large drop in employment in the immediate aftermath of the shock raises the question of why adjustment in the labor market takes place to such a large extent through employment rather than wages. One possible interpretation of this result is that it constitutes further evidence of wage rigidities in the labor market in the face of shocks.

\footnotetext{
${ }^{10}$ The impulse responses are calculated under the hypothesis that the current innovations in GDP affect employment and investment but not vice versa. The fact that the elements on the diagonal of the variance-covariance below are much bigger than the off-diagonal elements confirm that alternative orderings of the variables in the system would produce similar results.

Variance-covariance matrix of the VAR equations:

$4.3792 \mathrm{e}-004$

$1.1842 \mathrm{e}-005 \quad 3.6276 \mathrm{e}-004$

$1.1775 \mathrm{e}-006 \quad 8.8215 \mathrm{e}-006 \quad 3.6228 \mathrm{e}-005$

11 Total factor productivity also drops sharply in the first year after the shock. This is consistent with the result that changes in a country's economic growth over relatively short time intervals are primarily accounted for by changes in total factor productivity growth (Easterly et al., 1993).
} 
Figure 5. Spain: Impulse Responses and Confidence Intervals
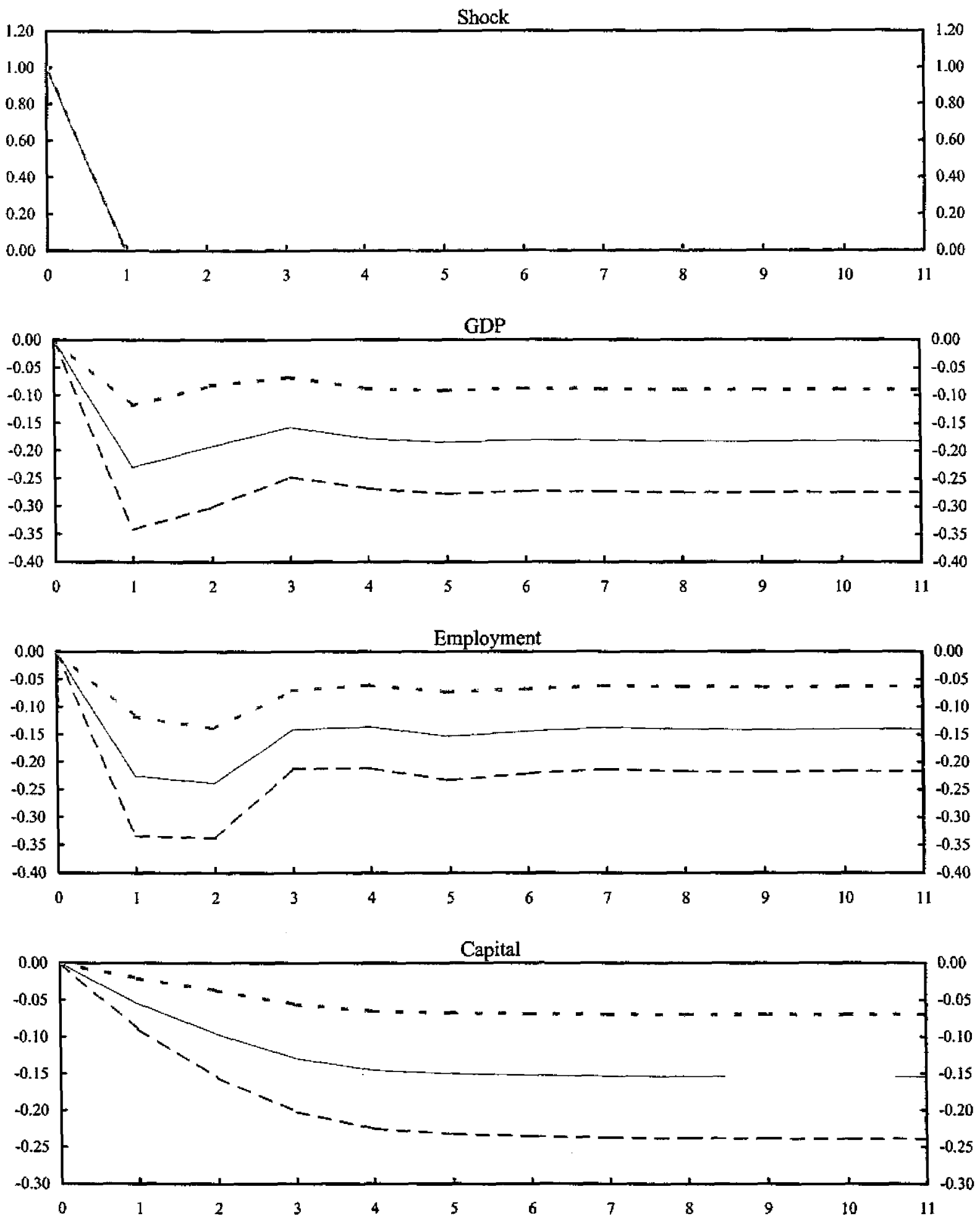

Source: Staff calculations. 


\section{Concluding Remarks}

26. This chapter has analyzed developments in private physical capital in the Spanish regions. Long-run movements in private physical capital across the Spanish regions seem to have taken place in accordance with relative returns. Controlling for human capital and physical capital, private investment has been higher in regions with a relatively low stock of private capital, and this has been mirrored in convergence of private capital per worker ratios. However, returns to private physical capital have not been significantly higher in highunemployment regions; accordingly, developments in private physical capital have not helped reduce differences in unemployment rates among regions.

27. Differences in the stock of private capital per worker seem to have been the main factor accounting for differences in returns on private capital among the Spanish regions, with differences in public capital and human capital accounting for much less. It therefore seems unlikely that policies aimed at changing relative human capital and public capital allocations could significantly alter any of the patterns described above.

28. The chapter has also analyzed the short-run response of capital and labor to shocks. When an adverse shocks hits a region, capital adjusts, but slowly; by contrast, employment drops sharply in the immediate aftermath of the shock, and subsequently rises somewhat. After about four years, the capital/labor ratio returns to its preshock level. A possible interpretation of these findings is that wages are rigid, implying that the brunt of the adjustment to regional shocks must be borne by employment rather than wages. 


\section{REFERENCES}

Blanchard, Olivier Jean and Lawrence F. Katz, 1992, "Regional Evolutions," Brookings Papers on Economic Activity: 1, Brookings Institute, pp. 1-75.

Decressin, Jörg, and Antonio Fatás, 1995, "Regional Labor Market Dynamic in Europe" European Economic Review, Vol. 39, pp. 1627-55.

William Easterly, Michael Kremer, Lant Pritchett, and Lawrence H. Summers, 1993, "Good Policy or Good Luck? Country Growth Performance and Temporary Shocks," Journal of Monetary Economics, Vol. 32, pp. 459-83.

García-Greciano, Begoña, and José Luis Raymond, 1999, "Las Disparidades Regionales y la Hipótesis de Convergencia: una Revisión," Papeles de Economia Española. Vol. 80, pp. 2-18.

Davis, Steven J., Prakash Loungani, and Ramamohan Mahidhara, 1995, "Regional Unemployment Cycles," mimeo, University of Chicago.

Dolado, Juan José, José Manuel Gonzáles-Páramo, José Roldán, 1994, "Convergencia Económica Entre las Provincias Españolas: Evidencia Empirica (1955-89)," Moneda y Crédito, Vol. 198, pp. 81-120.

Lucas, Robert E., Jr., 1990, "Why Doesn't Capital Flow from Rich to Poor Countries?" American Economic Review, Papers and Proceedings, Vol. 80, pp. 92-96.

Mauro, Paolo, and Antonio Spilimbergo, 1999, "How Do the Skilled and Unskilled Respond to Regional Shocks? The Case of Spain," Staff Papers, International Monetary Fund, Vol. 46, pp. 1-17.

Mauro, Paolo, Eswar Prasad, and Antonio Spilimbergo, 1999, "Perspectives on Regional Unemployment in Europe," IMF Occasional Paper No. 177 (Washington: International Monetary Fund.

Ramey, Valerie A., Matthew D. Shapiro, 2000, "Displaced Capital: A Study of Aerospace Plant Closings," NBER Working Paper (Cambridge, Massachusetts: National Bureau of Economic Research). 


\section{DATA SOURCES}

The data on human capital are drawn from Instituto Valenciano de Investigaciones Económicas, available via the Internet at http://www.ivie.es. The human capital index is employment with secondary or higher education as a share of total employment.

The data on private capital, public capital, gross domestic product, and employment are drawn from Fundación Banco Bilbao Vizcaya, and are available via the Internet at http://bancoreg.fbbv.es

The price of oil and the terms of trade index are drawn from the IMF's International Financial Statistics. A geometric average of the U.S. and German deflators is used to deflate the price of oil.

The data used to compute the shares of manufacturing employment in total employment are drawn from the Instituto Nacional de Estadistica. 
This appendix reports the results of a panel regression of the regional capital/labor ratio on its lag, human capital, public capital, yearly dummies to control for nationwide developments, and regional dummies. This specification can be thought of as a reduced form of a system consisting of two equations: a Cobb-Douglas production function and an investment equation.

Table 1. Dependent Variable $\mathbf{I}_{t}$

\begin{tabular}{lrrr}
\hline & & Standard Error & \multicolumn{1}{c}{$\mathrm{t}$} \\
\hline $\mathrm{I}_{\mathrm{t} \cdot \mathrm{l}}$ & Coefficient & 0.045 & 6.366 \\
$\ln (\mathrm{K} / \mathrm{L})_{\mathrm{l}-1}$ & 0.284 & 0.012 & -5.020 \\
$\ln (\mathrm{P} / \mathrm{L})_{\mathrm{l}-1}$ & -0.058 & 0.09 & -1.926 \\
$\ln (\mathrm{H} / \mathrm{L})_{\mathrm{l}-1}$ & -0.018 & 0.013 & -0.810
\end{tabular}

$\mathrm{R}^{2}=0.5512$

Note: There are 510 observations. The list of right-hand-side variables also includes 17 regional dummies and 29 yearly dummies, whose coefficients are not reported for the sake of brevity. 


\section{An Analysis of the Role of Public Capital in Regional Growth in Spain ${ }^{1}$}

1. This appendix examines empirically the impact of public capital on economic performance in Spain. Over the last decade, the role of public capital in the production process has received considerable attention from economists. The issue of whether and how public investment contributes to output growth is key to assessing the appropriate role of the state in creating an environment supportive of economic development. From a Spanish perspective, an analysis of the role of public capital in growth is especially critical for two reasons. First, per capita incomes in Spain remain about 15-20 percent below the average for the EU, a gap that may be attributable in part to shortfalls in infrastructure: at the beginning of the 1990s, the length of paved roads and railroad tracks per square kilometer of area were significantly lower in Spain than in some other major European countries. ${ }^{2}$ Second, substantial disparities exist in per capita incomes across regions in Spain. Higher levels of public investment generally, and particularly in relatively disadvantaged areas, could accelerate the convergence process not only between Spain and the EU average but also across regions within Spain.

2. A number of studies have attempted to investigate empirically the effect of government infrastructure investments on private sector productivity and growth, typically by estimating a production function based on public and private capital and labor. Most of these studies have found a positive and statistically significant effect of public capital on output growth, although typically with elasticities that are implausibly high: Aschauer (1989), Munnell (1990a) and Holtz-Eakin (1988), for example, find elasticities of public capital in the United States on the order of 0.3 to 0.4 , larger than the elasticities obtained for private capital. These studies have also tended to find that the more disaggregated the data set, the smaller is the observed impact of public investment on output: using data from American states, Munnell (1990b), and Costa et al. (1987), report positive, but smaller, elasticities (on the order of 0.2), and Hulten and Schwab (1991) and Holtz-Eakin and Schwartz (1994) find that infrastructure investment by states has little explanatory power regarding their growth experience. ${ }^{3}$

3. A small number of studies have examined the impact of public capital on output in Spain, typically confirming an important role for public capital. For example, Argimon et al.

${ }^{1}$ Prepared by Elisa Muzzini (Summer Intern).

${ }^{2}$ At the beginning of the $1990 \mathrm{~s}$, Spain had approximately 0.5 kilometer of paved road and 0.04 kilometer of railroad track per square kilometer of area. By contrast, these ratios were 1.4 and 0.06 for France, 1.4 and 0.12 for Germany, and 1.0 and 0.09 for Italy. World Bank (1994) World Development Report.

${ }^{3}$ For a summary of this literature, see Philip Gerson "The Impact of Fiscal Policy Variables on Output Growth" IMF Working Paper 98/1 (January 1998). 
(1993) find that public capital has a large and statistically significant impact on productivity at a national level, while Mas et al. (1998) find an elasticity of about 0.1 for public capital conducting the same exercise at a regional level.

4. The results of these production function studies-and in particular the very large elasticities for public capital that they have obtained-have been criticized on a number of grounds. First, because the production function approach is static, it does not allow for an analysis of the dynamics associated with the public investment process. Specifically, the production function approach does not allow an examination of the interactions, over several periods, of public capital, private capital, labor supply and output. In addition, problems of simultaneity may exist, because increases in public investment will affect aggregate demand in the short run, introducing a potentially spurious short-run correlation between public investment and aggregate supply. In addition, there are concerns that some of the early studies of the impact of public capital on investment may have omitted important explanatory variables or failed to account for the presence of unit roots in some of the variables in the analyses. Finally, concerns have been addressed on theoretical grounds about the wisdom of including public capital as an input to the production process, given that its supply is not under the control of private sector agents nor can it easily be substituted for labor or private capital.

5. This appendix addresses these concerns by analyzing the impact of public capital on output through two different empirical techniques: a stochastic frontier approach and a panel vector autoregression. The stochastic frontier approach recognizes that public capital can play an important role in increasing output and productivity growth, but eschews modeling public capital as an explicit input in the production process. Instead, the technique assumes a production function that is based on private capital and labor supply. The role of private capital is not to contribute to the production function directly, but rather to reduce technical inefficiency by reducing the gap between actual and potential output. The panel VAR approach, meanwhile, allows for greater interaction among all the variables of interest, allowing one to assess the impact of a temporary increase in public capital on private capital and labor. The analysis draws on detailed data sets on income, labor, private capital, public capital, and human capital for the 17 Spanish regions covering the period 1980-95 and collected by the Instituto Valenciano de Investigaciones Económicas and Fundación Banco Bilbao Vizcaya

\section{The Stochastic Frontier Approach}

6. As noted above, the stochastic frontier approach (as, for example, employed by Delorme et al. (1999)), uses observed data on inputs and outputs to estimate a production possibilities frontier, with the gap between the frontier and actual output constituting the degree of technical inefficiency. The approach then uses regression analysis to attempt to identify the factors explaining the degree of inefficiency. Early studies adopted a two stage estimation technique, first calculating the extent of technical inefficiency and then separately regressing it on a set of explanatory variables, but more recently Battese and Coelli (1995) have developed a one-step approach to simultaneously estimate the stochastic frontier and the 
factors accounting for observed inefficiencies, and this single-step approach is used in this analysis.

7. Specifically, the stochastic frontier production model with panel data can be written as

$$
Y_{i t}=f\left(X_{i t} \beta\right) e^{\left(\varphi_{i t}+u_{i i}\right)}
$$

where

$Y_{i r}$ is output for region $i$ at time $t$

$X_{i t}$ is a $1 \times k$ vector of inputs;

$\beta$ is a $k \times 1$ vector of unknown parameters to be estimated;

$v_{i t}$ are independent and identically distributed random errors with mean zero and variance $\sigma_{*}^{2}$

$u_{i t}$ are non-negative, unobservable random variables (with variance $\sigma_{u}^{2}$ ) associated with the technical inefficiency of production, such that, for the given technology and level of inputs, observed output falls short of potential output.

Putting equation (1) in logs and assuming a Cobb-Douglas production function, we obtain

$$
y_{i t}=x_{i t} \beta+v_{i t}+u_{i t}
$$

where lower-case letters represent natural logs of their upper-case counterparts. As noted above, we model the error associated with technical inefficiency, $u$, as a function of a set of explanatory variables. Specifically, we assume

$$
u_{i t}=z_{i t} \delta+w_{i t}
$$

where $z$ is a vector of explanatory variables associated with the technical inefficiency effects; $\delta$ is a vector of parameters to be estimated, and the $w$ are unobservable random variables, assumed to be independently distributed over a truncated normal distribution with mean zero and unknown variance such that $u$ is non-negative. The technical inefficiency effects are thus assumed to be independent, non-negative truncations of normal distributions with unknown variance and mean $z_{i t} \delta$ for $i=1, \ldots, \mathrm{N}$ and $t=1, \ldots, \mathrm{T}$. The mean can therefore differ across regions and time periods, but the variance is assumed to be identical across both. We can define the variance parameter $\gamma=\sigma_{u}^{2} /\left(\sigma_{v}^{2}+\sigma_{u}^{2}\right)$ as the share of the random error in the model that is arising from inefficiency effects. 
8. As noted above, we model the production function as Cobb-Douglass, with output depending on labor and private capital, as well as on a trend. Technical inefficiency is modeled as a function of the ratio of public to private capital; the share of public investment that goes to infrastructure; the share of public investment that goes to health and education; and a series of other variables including the output gap on a nationwide basis (to correct for the impact of the business cycle), a time trend, regional dummies, and the stock of human capital (measured as the percentage of workers who have obtained at least a middle school education). Following Battese and Coelli, we employ maximum likelihood techniques to simultaneously estimate the parameters of the stochastic production frontier and the technical inefficiency effects model. Table 1, below, gives the results of the estimation procedure.

9. Starting with the results for the stochastic production function, the results suggest the presence of constant returns to scale in production, with the elasticities of capital and labor approximately equal. ${ }^{4}$ The high elasticity obtained for private capital is similar to that obtained by Mas et al. (1998). The variance parameter $\gamma$ provides an estimate of the degree of systemic inefficiency, with the results indicating that some 26 percent of the random error in the model is arising from technical inefficiency effects.

10. Turning to the estimation of the factors accounting for technical inefficiency, the results suggest that all of the variables with the exception of the trend and the share of investment going to health and education are significant in explaining differences in technical inefficiency actoss regions. As expected, relatively high endowments of public capital (scaled for the stock of private capital), and high public infrastructure (scaled for overall public capital) lead to significant reductions in regional inefficiency. That is, they move a region closer to the production possibilities frontier. By contrast, relatively high stocks of public investment in health and education have little impact in reducing technical inefficiency, although this is after controlling for the level of human capital in a region. Higher levels of human capital do indeed reduce technical inefficiency.

11. These results are therefore consistent with an interpretation that higher levels of public investment can have a positive impact on output, within limits. Specifically, higher public investment can raise output by reducing technical inefficiencies in production, perhaps through the elimination of bottlenecks due to shortfalls in infrastructure. The modeling strategy adopted, however, would imply that once technical inefficiencies are eliminated or minimized, further public capital investment can have little impact on output. This would argue for a policy of continued-but highly targeted--public investment to support output growth.

\footnotetext{
${ }^{4}$ A log-likelihood test for missepecification rejects a translog specification in place of the Cobb-Douglas specification used here. In addition, a log-liklihood test does not reject the null hypothesis of constant returns to scale in the production function.
} 
Table 1. Maximum-likelihood Estimates for Parameters of the Stochastic Frontier and Inefficiency Effect Model

\begin{tabular}{|c|c|c|c|}
\hline Variable & Parameter & Coefficient & t-ratio \\
\hline \multicolumn{4}{|l|}{ Stochastic Frontier Model } \\
\hline Constant & $\beta_{0}$ & $\begin{array}{l}4.048 \\
(0.435)\end{array}$ & 9.299 \\
\hline Trend & $\beta_{1}$ & $\begin{array}{c}0.009 \\
(0.000)\end{array}$ & 6.453 \\
\hline Labor & $\beta_{2}$ & $\begin{array}{c}0.512 \\
(0.047)\end{array}$ & 10.966 \\
\hline Private Capital & $\beta_{3}$ & $\begin{array}{c}0.464 \\
(0.002)\end{array}$ & 9.735 \\
\hline \multicolumn{4}{|c|}{ Inefficient effect model with region specific effects } \\
\hline Trend & $\delta_{1}$ & $\begin{array}{l}-0.001 \\
(0.003)\end{array}$ & -0.139 \\
\hline Output Gap & $\delta_{2}$ & $\begin{array}{l}-0.601 \\
(0.092)\end{array}$ & -6.509 \\
\hline Human Capital & $\delta_{3}$ & $\begin{array}{l}-0.403 \\
(0.118)\end{array}$ & -3.395 \\
\hline$\%$ Public Capita/ Private Capital & $\delta_{4}$ & $\begin{array}{l}-2.327 \\
(0.483)\end{array}$ & -4.814 \\
\hline$\%$ Infrastructure/Public Capital & $\delta_{5}$ & $\begin{array}{l}-1.120 \\
(0.214)\end{array}$ & -5.225 \\
\hline$\%$ Health \& Education/Public Capital & $\delta_{6}$ & $\begin{array}{l}0.329 \\
(0.255)\end{array}$ & 1.290 \\
\hline Variance Parameters & $\sigma^{2}$ & 0.001 & 10.098 \\
\hline & $\gamma$ & 0.263 & 3.375 \\
\hline
\end{tabular}

Notes:

(1) Standard errors are in parenthesis;

(2) The t-ratios are asymptotic. 


\section{The Panel VAR Approach}

12. As noted earlier, one liability of production function-based approaches to studying the impact of public investment on output is that they do not allow one to capture interactions among public and private capital and labor supply. In addition, the production function approach does not allow one to examine the long-run impact of public investment on output, and thus leaves open the potential for spurious correlations between investment and long-run supply caused by the short-run impact of higher investment on aggregate demand. To address these concerns, a panel vector autoregression was conducted to examine the interactions of public capital, private capital, labor and output.

13. The panel VAR was estimated in log levels for the period 1980-95, using data for all 17 regions. Because of the very high correlation between private capital and employment, all variables were restated in per worker terms, with the model thus reduced to three variables: public capital per worker, private capital per worker, and output per worker. Two different measures of public capital were used: the overall stock of public capital, and the stock of public infrastructure. A time trend and 17 regional dummies were also included as exogenous variables to account for the possibility of regional structural differences. The model was estimated using two lags, as indicated by both the Schwartz-Bayesian and Akaike Information Criteria. The resulting error matrix was orthogonalized using the Cholesky decomposition.

14. We assume the following causal ordering of variables: shocks to public capital per worker contemporaneously affect both other endogenous variables, while those to private capital per worker contemporaneously affect only output per worker. Shocks to output per worker have no contemporaneous impact on either of the other endogenous variables, although feedback effects are allowed across all variables subsequent to the initial shock. Unfortunately, the results are sensitive to the ordering of the shocks, meaning that the findings should be interpreted with caution.

15. Figure 1 illustrates the impulse responses of public capital per worker, private capital per worker, and output per worker for a transitory unit shock to the stock of public capital per worker. While a unit shock to public capital has no long-run effect on private capital or output, it does has a significant, positive short-run effect. ${ }^{5}$ The duration of a shock is about 10 years, and its amplitude is significant for about five years. Thus, while higher public investment cannot permanently raise output, it can do so for a substantial period of time, perhaps beyond that which could be accounted for solely through the effect of public investment on aggregate demand. While public infrastructure investment also has a positive short-run impact on private capital and output, the effects are generally stronger for the total

\footnotetext{
${ }^{5}$ It is worth noting that this result depends critically on the introduction of regional dummy variables. When these variables are excluded the long-run impact of a shock to public capital is significant and positive.
} 
Figure 1. Spain: Impulse Response Functions from Panel VAR

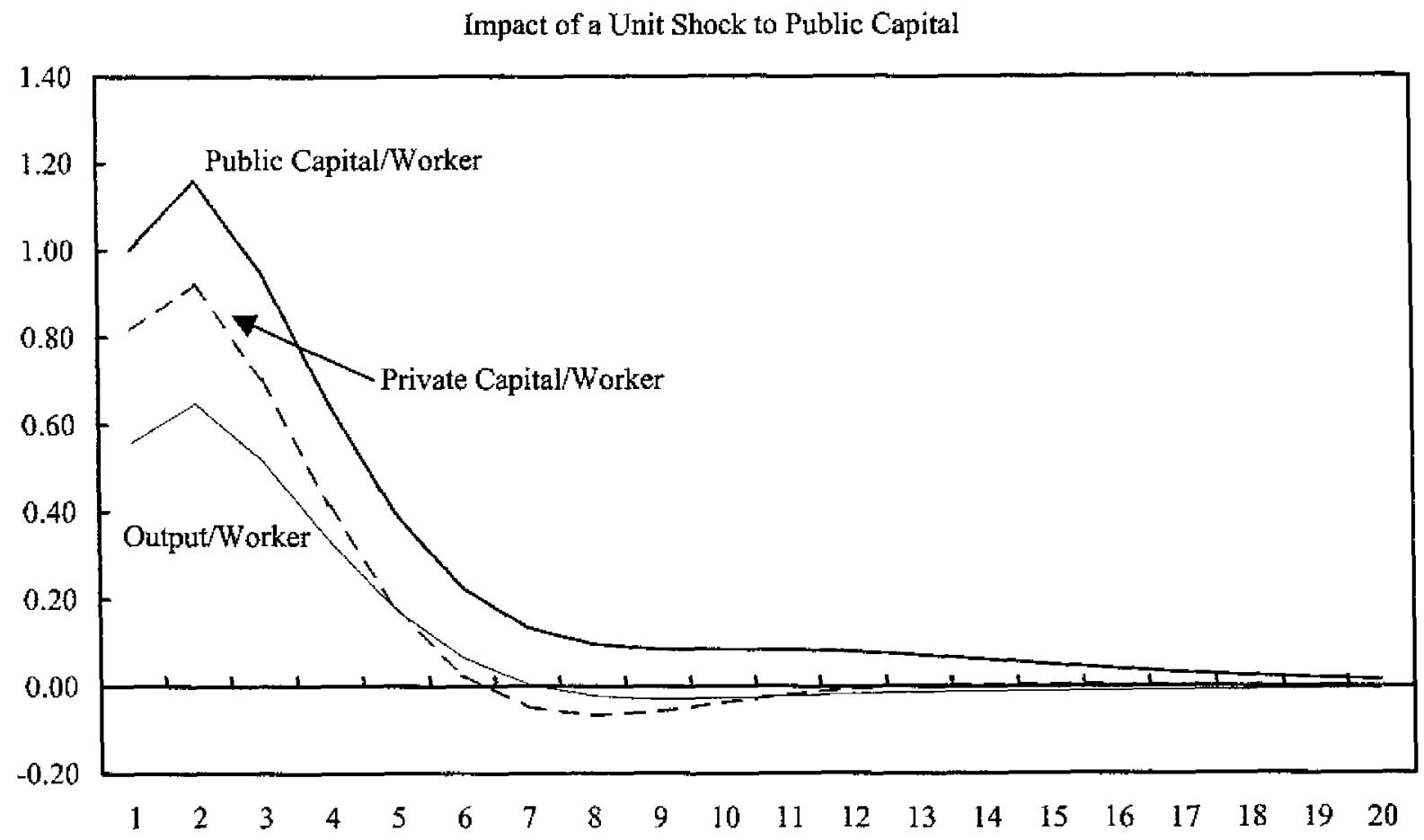

Impact of a Unit Shock to Public Infrastructure

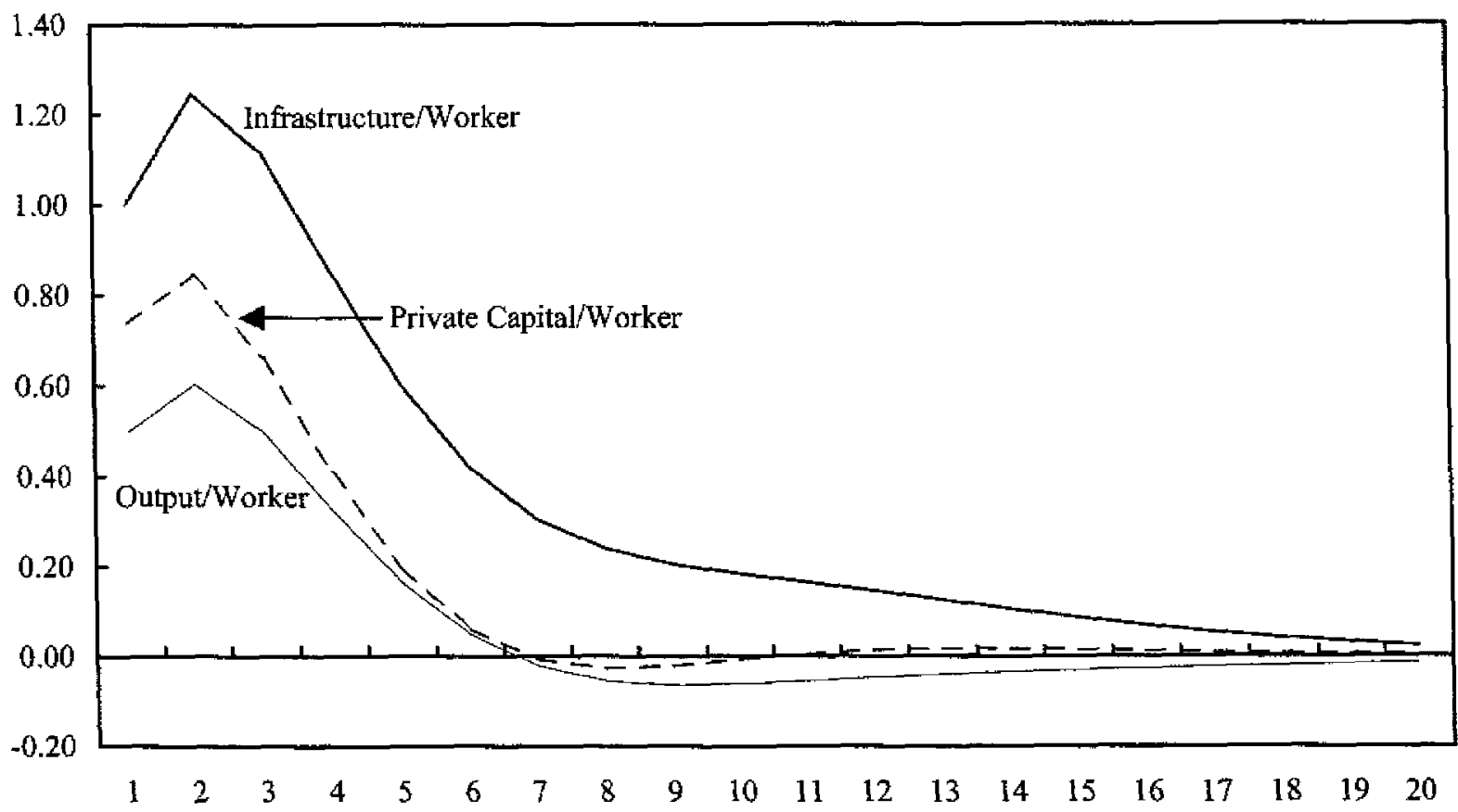

Source: Staff Calculations 
stock of public capital than for public infrastructure capital alone. The results also imply that public investment does not crowd out private investment. Instead, at least in the short run higher public investment crowds in the private sector, with private capital per worker responding positively to a unit shock to public capital per worker. However, these results must be interpreted cautiously, given that the results depend significantly on the ordering of the variables.

\section{Conclusions}

16. This appendix has examined the impact of public capital investment on output in Spain, drawing on panel data covering the period $1980-95$ for the 17 regions. While previous empirical work has tended to find an important role for public capital in stimulating output in Spain-particularly at a national level - this work has relied on a production function approach that includes public capital along with private capital and labor supply as inputs in the production process. This approach has been challenged on both theoretical and empirical grounds, among other reasons because it treats public capital as being fully substitutable for private capital and labor and because it does not allow for potential interactions among public and private capital and the supply of labor.

17. To address these problems, this appendix has made use of two different empirical techniques. First, a stochastic production function model was estimated in which public capital does not enter the production process directly but instead contributes to moving a region closer to the production possibilities frontier. Secondly, a VAR was estimated to allow feedback effects among public and private capital and output. The results of the analysis are consistent with a positive role for public capital (and public infrastructure capital) in stimulating output. Higher public capital is shown as contributing significantly to reducing technical inefficiency across regions, perhaps by eliminating bottlenecks in the production process. This would imply that a program of well-targeted public investment could-within limits--play a positive role in stimulating output growth, at least until technical inefficiencies have been minimized. The VAR results-while tentative-also suggest that higher public capital investment can stimulate output growth, at least in the medium term, both through its direct effect on output and by encouraging higher levels of private investment, as well. 


\section{References}

Argimón, Isabel, J.M. Gonzáles-Páramo, M.J. Martín and José M. Roldán, 1993, "Productivity and Infrastructure in The Spanish Economy", Bank of Spain Working Paper No. 9313 (Madrid: Bank of Spain).

Aschauer, David, 1989, "Is Public Expenditure Productive?" Journal of Monetary Economics, vol. 23, pp. 177-200.

Battese, G.E. and T.J. Coelli, 1995, "Model for Technical Inefficiency Effects in a Stochastic Frontier Production Function for Panel Data," Empirical Economics vol. 20, pp. 325-32.

Costa, J. da Silva et al., 1987, "Public Capital, Regional Output and Development: Some Empirical Evidence," Journal of Regional Science vol. 27, pp. 419-37.

Delorme, Charles D., H.G. Thompson and Ronald S. Warren, 1999 , "Public Infrastructure and Private Productivity: A Stochastic-Frontier Approach", Journal of Macroeconomics, vol. 21 pp. 563-76.

Holtz-Eakin, Douglas, 1998, "Private Output, Govemment Capital and the Infrastructure 'Crisis'," Discussion Paper 394 (New York: Columbia University Department of Economics).

Holtz-Eakin, Douglas and Amy E. Schwartz, 1994, "Infrastructure in a Structural Model of Economic Growth," NBER Working Paper 4824 (Cambridge: National Bureau of Economic Research).

Hulten, Charles R. and Robert W. Schwab, 1991, "Public Capital Formation and the Growth of Regional Manufacturing Industries," National Tax Journal vol. 44, no. 4, pp. 121-34.

Mas, Matilde, J. Maudos, F. Perez and Ezequiel Uriel, 1998, "Public Capital, Productivity Efficiency and Convergence in the Spanish regions (1964-93)", The Review of Income and Wealth, vol. 44, 383-96.

Munnell, Alicia, 1990", "Why Has Productivity Growth Declined?" New England Economic Review vol. 1, no. 3, pp.3-22.

Munnell, Alicia, 1990b, "How Does Public Infrastructure Affect Regional Economic Performance?" in Is There a Shortfall in Public Capital Investment? ed. by A. Munnell, (Boston: Federal Reserve Bank of Boston). 